\title{
Importance of immune monitoring approaches and the use of immune checkpoints for the treatment of diffuse intrinsic pontine glioma: From bench to clinic and vice versa (Review)
}

\author{
JORGE AUGUSTO BORIN SCUTTI \\ Immunotherapy Platform, Immunology Department, MD Anderson Cancer Center, Houston, TX 77054, USA
}

Received October 24, 2017; Accepted February 1, 2018

DOI: $10.3892 /$ ijo.2018.4283

\begin{abstract}
On the basis of immunological results, it is not in doubt that the immune system is able to recognize and eliminate transformed cells. A plethora of studies have investigated the immune system of patients with cancer and how it is prone to immunosuppression, due in part to the decrease in lymphocyte proliferation and cytotoxic activity. The series of experiments published following the demonstration by Dr Allison's group of the potential effect of anti-cytotoxic T lymphocyteassociated antigen-4 (CTLA-4) paved the way for a new perception in cancer immunotherapy: Immune checkpoints. Several T cell-co-stimulatory molecules including cluster of differentiation (CD)28, inducible T cell co-stimulatory, 4-1BB, OX40, glucocorticoid-induced tumor necrosis factor receptorrelated gene and CD27, and inhibitory molecules including $\mathrm{T}$ cell immunoglobulin and mucin domain-containing-3, programmed cell death-1 (PD-1), programmed cell death ligand-1 (PD-L1), V-domain immunoglobulin suppressor of $\mathrm{T}$ cells activation, $\mathrm{T}$ cell immunoglobulin and immunoreceptor tyrosine-based inhibitory motif domain, and $\mathrm{B}$ and $\mathrm{T}$ lymphocyte attenuator have been described in regulating $\mathrm{T}$ cell functions, and have been demonstrated to be essential targets in immunotherapy. In preclinical studies, glioblastoma multiforme, a high-grade glioma, the monotherapy targeting PD-1/PD-L1 and CTLA-4 resulted in increased survival times. An improved understanding of the pharmacodynamics and immune monitoring on glioma cancers, particularly in diffuse intrinsic pontine glioma (DIPG), an orphan type of cancer, is expected to have a major contribution to the development of novel therapeutic approaches. On the basis of the recent preclinical and clinical studies of glioma, but not of DIPG,
\end{abstract}

Correspondence to: Dr Jorge A.B. Scutti, Immunotherapy Platform, Immunology Department, MD Anderson Cancer Center, 7455 Fannin Street SCR3.3020 Unit 901, Houston, TX 77054, USA E-mail: jascutti@mdanderson.org

Key words: immune monitoring, immune checkpoint, diffuse intrinsic pontine glioma the present review makes a claim for the importance of investigating the tumor microenvironment, the immune response and the use of immune checkpoints (agonists or antagonists) in preclinical/clinical DIPG samples by immune monitoring approaches and high-dimensional analysis. Evaluating the potential predictive and correlative biomarkers in preclinical and clinical studies may assist in answering certain crucial questions that may be useful to improve the clinical response in patients with DIPG.

\section{Contents}

1. Introduction

2. Immune checkpoint blockade as a potential approach to treat patients with cancer

3. Glioma and DIPG

4. Immune system, gliomas and neoantigens

5. Cancer immunoediting in glioma

6. Immune monitoring approaches to DIPG

7. Conclusions

\section{Introduction}

Cancer exhibits a range of symptoms of differing severity, from mild ailments including headaches to complete organ failure; therefore, it is no surprise that cancer has been described as 'The Emperor of All Maladies' (1). Cancer has become so pervasive in the USA that, for many, a diagnosis of the disease is almost synonymous with a death sentence, and the statistics illustrate why. The American Cancer Society reported that, in 2016, there were $\sim 1.7$ million novel diagnoses of the disease and $\sim 600,000$ associated mortalities (2). For years, cancer therapy has been relatively unchanged, with surgery, radiotherapy and chemotherapy the three primary methods used to treat patients with cancer. Surgery offers a great chance for a cure for many types of cancer, principally those that have not metastasized. Radiotherapy is involved in many treatments of cancer; however, severe side effects can occur months to years following treatment. Additionally, certain tumor cells are resistant enough to tolerate, and recover from, the damage to their DNA caused by radiation therapy $(3,4)$. Although 
chemotherapy remains an effective treatment for many types of cancer, it typically leads to side effects including fatigue, pain, diarrhea, nausea and vomiting, and blood and nervous system disorders (5). Resistance to several chemotherapeutic agents and molecularly targeted therapies, including vemurafenib, imatinib, nilotinib, erlotinib and trastuzumab, is the primary issue regarding current cancer research. These drugs are designed to discern molecularly transformed cells that may express, for instance, high levels of BRAF mutant, breakpoint cluster region-Abelson, epidermal growth factor receptor (EGFR) and human epidermal growth factor receptor 2 (HER2), from non-transformed cells. Through natural selection, transformed cells submitted to molecularly targeted therapies have also developed to escape from these therapies. Alterations in the drug target, activation of prosurvival pathways and ineffective induction of cell death are examples $(6,7)$.

Hanahan and Weinberg $(8,9)$ proposed a hypothesis in their observations defining critical aspects of cancer pathophysiology: Forms of symptomatic neoplastic disease and their association with acquired biological capabilities enable cancer cells to proliferate. They proposed to call this set of biological capabilities 'hallmarks of cancer'. Currently, in their conceptualization, there are eight hallmark capabilities that are common to a number, if not the majority, of forms of human cancer: Sustaining proliferative signaling, evading growth suppressors, resisting cell death, enabling replicative immortality, inducing angiogenesis, activating invasion and metastasis, deregulation of cellular energetics and metabolism, and avoiding immune destruction $(8,9)$. Somehow, all these aspects impair the effectiveness of the therapy against cancer cells. Certain strategies, including cytokines (10), signal transduction inhibitors (11), oncolytic viruses (12) and angiogenesis inhibitors (13), have been attempted, generally with low rates of positive response. Thus, there is an urgent requirement to develop novel therapies for treating cancer.

A rapid increase in comprehending the mechanistic pathway of these principles, particularly avoiding immune destruction, has led to clinical success in the treatment of cancer. Robert Schreiber and Lloyd J. Old (the 'father of tumor immunology') demonstrated that T lymphocytes and interferon- $\gamma$ (IFN- $\gamma$ ) assisted in inhibiting the development of spontaneous cancer in mice lacking the expression of recombination-activating 2, a gene which encodes a protein involved in the V(D)J recombination during $\mathrm{T}$ and $\mathrm{B}$ cell development (14). They also contributed in describing immunoediting and how cancer cells became less immunogenic than the starting population (15-19). Immunoediting is discussed in the present review. Currently, the function of the immune system in the recognition and elimination of cancer cells is beyond any doubt. The potential use of immunotherapy is to restore the immune system of patients in the attempt to stimulate it to reject and destroy tumors $(20,24)$. Strategies including dendritic cellbased immunotherapy, T cell adoptive transfer, autologous immune enhancement therapy and genetically engineered $\mathrm{T}$ cells are being, with positive results, developed to improve the quality of life and increase the survival rates of patients with cancer (21,23-25). Recently, T cells have been genetically engineered to create specialized receptors on their surfaces known as chimeric antigen receptors (CARs), a personalized treatment that involves genetically modifying a patient's $\mathrm{T}$ cells to make them a target $(24,26,27)$. Furthermore, there are several approaches for cancer immunotherapy already approved by the US Food and Drug Administration (FDA) or remain under investigation: Adjuvant therapy (recombinant Listeria, stimulator of IFN genes and Toll-like receptor agonist); adoptive T-cell therapy [autologous T cells, CAR-T cells and $\mathrm{T}$ cell receptor (TCR) transgenic $\mathrm{T}$ cells]; cytokine therapy [interleukin-2 (IL)-2, IFN- $\gamma$, IL-15, IL-18 and tumor necrosis factor- $\alpha$ (TNF- $\alpha)$ ]; macrophage activation [cluster of differentiation (CD)40 agonists and CD47 antagonists]; natural killer (NK) cell therapy (ex vivo expanded NK cells); oncolytic virus therapy (engineered herpes simplex virus, measles virus and poliovirus); and vaccines (human papillomavirus vaccines and sipuleucel-T vaccine for prostate cancer) are class types and examples of cancer immunotherapy (25). However, in recent years, a novel and surprisingly effective method of immunotherapy has arisen: The immune checkpoint blockade. This novel form of therapy does not target cancer cells and also does not involve cytokines or vaccines to turn on the immune response; rather, it works by blocking inhibitory pathways (26). The best characterized of these immune checkpoints are cytotoxic T-lymphocyte-associated protein antigen-4 (CTLA-4) and programmed cell death-1 (PD-1). Immune checkpoint inhibitors blocking CTLA-4 and PD-1 molecules were approved by the FDA in 2011 and 2014, respectively. The present review makes a claim for the importance of investigating the tumor microenvironment (TME), the immune response and the use of immune checkpoint (agonists or antagonists) in preclinical/clinical diffuse intrinsic pontine glioma (DIPG) samples by immune monitoring approaches. The potential predictive biomarkers of tumor-associated cells and the TME in preclinical and clinical studies may assist in answering certain crucial questions that may be useful to improve the clinical response in patients developing DIPG, an orphan type of cancer representing the principal cause of mortality from pediatric brain tumors.

\section{Immune checkpoint blockade as a potential approach to treat patients with cancer}

Cancer immunotherapy was declared as the 'Breakthrough of the Year' in 2013 (28). The ecstasy is primarily grounded on a numberof clinical successes of antibodies thatmodulateimmune checkpoints mainly by targeting CTLA-4 and PD-1 (29). The idea of checkpoint blockade and consequently the renaissance of cancer immunotherapy, emerged when Dr James Allison's group interrogated why $\mathrm{T}$ cells were not being fully activated to attack cancer cells (30). The answer to the initial question led to the identification of a molecule called CTLA-4. This molecule exhibited a marked structural homology with CD28, but its function in stimulating or in dampening $\mathrm{T}$ cell activation was not completely understood. However, data provided by Tivol et al (31) and Waterhouse et al (32), using knockout mice, definitively revealed the inhibitory function of CTLA-4. The sequence of experiments in these studies paved the way to a new perception in cancer immunotherapy: Immune checkpoint blockade. In a preclinical study, the combination of anti-CTLA-4 and anti-PD-1 was more than twice as efficient as either therapy alone in generating an effector immune 
response against murine melanoma and colon adenocarcinoma $(33,34)$. The approval of immune checkpoint blockade targeting the CTLA-4 and PD-1 pathway motivated the interest in exploiting antibodies which also induce $\mathrm{T}$ cell activation. Immune responses are tightly regulated by a system of checkpoints that control positively or negatively the magnitude of the immune response in a wide range. Besides CTLA-4 and PD-1, the presence of several inhibitory immune checkpoints that block $\mathrm{T}$ cell responses including $\mathrm{T}$ cell immunoglobulin mucin domain-3 (TIM-3), lymphocyte-activation gene-3 (LAG-3), $\mathrm{T}$ cell immunoglobulin and immunoreceptor tyrosine-based inhibitory motif domain (TIGIT), V-domain immunoglobulin suppressor of $\mathrm{T}$ cell activation (VISTA), B and $\mathrm{T}$ lymphocyte attenuator (BTLA), B7-H3 and B7-H4 have emerged as novel targets for immune checkpoint blockade strategies. Conversely, stimulating T cells directed to molecules including CD27, CD28, OX-40 (CD134), glucocorticoid-induced TNF receptor-related protein (GITR) and inducible T cell co-stimulator (ICOS) has been used for mobilizing the immune system to attack cancer cells (35-42). Immunotherapeutic approaches to treat patients with cancer have been evaluated in the last few decades and, currently, immune checkpoints are the new paradigm for treatment of cancer. The FDA approved the antibody against CTLA-4 (ipilimumab) in 2011 for the treatment of metastatic melanoma (43). Clinical trials for the treatment of non-small cell lung carcinoma, small cell lung cancer, bladder and metastatic hormone refractory prostate cancer are being implemented (44-48). Antibodies against PD-1 (pembrolizumab and nivolumab) were approved in 2014 by the FDA for the treatment of patients with melanoma that did not respond to prior treatment. Antibodies against CTLA-4, PD-1 and programmed cell death ligand-1 (PD-L1) have exhibited an objective response against several types of cancer in clinical trials with rates of $\sim 25 \%$ (49-52). This effect represents a particular challenge for immunotherapy, since certain types of cancer presented low mutation rates and high immune regulatory molecules, including VISTA, TIM-3, LAG-3 and TIGIT $(53,54)$.

Tumor growth and development is associated with immunomodulation of $\mathrm{T}$ cell responses through the enhancement of co-inhibitory molecules. As expected, different types of immune cell exert different effects on tumor progression. In the vast majority of solid cancer types, tumor infiltration by cytotoxic lymphocytes, Th1 profile and mature dendritic cells are associated with a good clinical outcome (55). Nonetheless, studies have indicated that the increase in $\mathrm{CD} 8^{+} \mathrm{T}$ cell infiltration is not always associated with a good prognosis in cancer, as could be observed in Hodgkin's lymphoma, diffuse large B-cell lymphoma, renal cell carcinoma, lung metastases from clear cell renal cell carcinoma and non-small cell lung cancer (56-60). These effects may be explained by the expression of immune checkpoints on infiltrating $\mathrm{T}$ cells or its ligands on tumor cells that are fundamental to immune escape in cancer. For instance, the anti-CTLA-4 (ipilimumab) therapy, which improved median overall survival in patients with metastatic melanoma (61), resulted in significant survival benefit in only $20 \%$ of patients. There is evidently a requirement to improve the therapeutic benefit of this treatment to more patients and also apply this approach, even if with only minimal success, to types of cancer with low survival rates, including DIPG. The immune monitoring studies of immune responses of patients to agents targeting immune checkpoints would be the best way to investigate the reasons for only a small proportion of patients with cancer responding to the treatment. The essential cause of resistance to immune checkpoint blockade may be explained through the failure of the effector T cells in becoming activated, mainly due to the low mutational neoantigen rates, the TME and the increase in co-inhibitory molecules which dampen T cell activity (62-64).

\section{Glioma and DIPG}

Brain cancer is rare for people of any age, but it may develop in children as well as in adults. When the supportive cells are transformed, and induced to proliferate by several mutation patterns, glial cancer known as glioma arises. The World Health Organization classifies glioma into low grade (grade I, pilocytic; grade II, fibrillary) or high grade [grade III, anaplastic; grade IV, glioblastoma multiforme (GBM)] (65). The capacity of gliomas to induce local and systemic immunosuppression restricts the immune response against tumor growth, development and progression, and it may impair the efficacy of immunotherapy (66). In this case, immune checkpoint agonists targeting GITR, ICOS, 4-1BB, OX40, CD27 and CD28 on the T cells may be a good strategy to improve clinical responses rates and also overcome the resistance to immunotherapeutic approaches in glioma. Accumulating evidence in clinical responses in a diverse group of advanced-stage cancer suggest that the combination with standard approaches and immunotherapy on the basis of immune checkpoints may also be beneficial. Brainstem glioma may be described by a diverse biological performance, and the prognosis and treatment depend on clinical symptoms, and their duration, location and mutational profile (67). The majority of pediatric brainstem gliomas begin within the pons, whereas the remaining $20 \%$ occur in the medulla, midbrain or cervicomedullary junction (68-72). Pontine cancer is a diffuse intrinsic brainstem glioma which behaves in an infiltrative manner and has a consistently poor prognosis (73).

DIPG is the pediatric malignancy with the poorest prognosis. It is defined as a high-grade glioma occurring in the ventral pons and accounts for between 10 and $15 \%$ of pediatric tumors of the brain, affecting an estimated 200-400 children of between 4 and 9 years of age in the USA annually (74). Conventional focal radiotherapy is the standard treatment for patients with DIPG; however, transient effects and minimal survival has been observed (75). Mutations in H3F3A or HIST3BHI which encode the histone H3.3 variant and H3.1, respectively, appear to be present in all DIPG cells (76-78). As a result of these mutations, a substitution of methionine for Lys $^{27}$ (K27M) occurs, causing an altered binding of mutant $\mathrm{H} 3$ to Polycomb repressive complex 2, an essential developmental regulator of gene expression and it appears to be the main event of DIPG oncogenesis $(79,80)$. Despite these mutations, the genomic landscape of DIPG cancer cells appear to have variations in activin A receptor type I, tumor protein 53, platelet-derived growth factor receptor A, phosphoinositide 3-kinase catalytic subunit $\alpha$ and c-Myc (81). Unfortunately, DIPG is not well understood, partly because of its low incidence, low biopsy and autopsy rates (82). 
In order to solve this issue and to contribute to DIPG research, the international DIPG Registry (dipgregistry.org), a central resource of clinical information combines co-operative efforts throughout physicians and researchers from North America, Europe and Australia to consolidate and standardize the collection of clinical data and tumor samples from patients with DIPG. The aim of this effort is to support innovative research and ultimately find a cure for DIPG.

Currently, DIPG is the primary cause of brain tumorassociated mortality among children, with a median survival time of $<1$ year and with a 5-year survival rate of $<1 \%$ (81). Their location within the brain and diffuse nature render them unfit for resection, and biopsies have rarely been conducted (83). The distribution of chemotherapeutic agents to the tumor has been prevented by the existence of the blood-brain barrier (BBB) and, even using the convectionenhanced delivery technique (CED), the effective dose has not been achieved (84). Doses of drugs that result in significant systemic toxicity have to be administered to obtain minuscule decreases in tumor growth (85). There have been $>250$ clinical trials designed at targeting several biological capabilities of DIPG and, despite numerous efforts, DIPGs have no effective treatment and no significant improvement has been made during the last 30 years (86). As aforementioned, DIPG is a type of cancer with epigenetic features that comprise histone modifications including methylation and acetylation. Certain agents targeting epigenetic factors including histone deacetylase inhibitors (HDACi; including panobinostat, vorinostat, belinostat, romidepsin and valproate) histone methylase and demethylase inhibitors, DNA methylation inhibitor and bromodomain and extra-terminal motif protein inhibitors are of importance in treating DIPG (87). Comprehending the epigenetic landscape of DIPG opened up the possibility for epigenetic modifiers, which may lead to regulation of this lethal cancer. Recently, several studies have demonstrated that HDACi including panobinostat or MS-275 (entinostat) are able to restore the aberrant gene expression associated with the K27M mutation, the dominant variation in genes encoding histones H3.3 and H3.1. Furthermore, HDACi are also able to enhance the immune response by increasing tumor-associated antigens (88), major histocompatibility complex (MHC) class I, II, CD40 (89) and NK cell-activating ligands (90). The effects of HDACi on immune cells have been reviewed previously (91). However, the potential molecular mechanism by which these agents upregulate or downregulate tumor ligands, $\mathrm{T}$ or NK cell molecules is unknown.

\section{Immune system, gliomas and neoantigens}

For a long time, the brain was believed to be devoid of a lymphatic system. However, this was idea was challenged in 2016 when Schläger et al (92) revealed that this system is part of the meninges (arachnoid and dura) and, even in physiological conditions, $\mathrm{T}$ cells do not cross the BBB; they are able to traffic between the leptomeninges and cerebrospinal fluid (CSF) through blood vessels (93). Furthermore, owing to the assumption that brain cancer is merely immunogenic, it was not considered that there was a function for the immune system in glioma. Immunotherapeutic strategies have altered this way of thinking, therefore important clinical trials in malignant glioma have been performed. At first, it was possible to realize, in principle, that tumor-associated antigens should be discernable to the immune system in the deep cervical lymph nodes and those immune cells would have access to brain cancer via the CSF and choroid plexus paths (94). Finally, as long as these barriers restrict access of immunotherapeutic approaches to the brain, certain strategies including direct infusion of antibodies, dendritic cells, T cells and other drugs by CED afford a possible opportunity for immediate delivery, decreasing the efflux of cells or molecules (95).

The lack of available and valuable cytotoxic therapies associated with prolonged poor clinical outcomes and the unmanageable landscape profile of DIPG warrant novel approaches that target DIPG cancer cells (96). Immunotherapy is being progressively considered as a 'weapon' for use in combination therapy or as a complementary approach to conventional treatments (97-100), particularly those that target glioma-associated antigens (GAAs). The function of the immune system and its importance in conferring protection against glioma development has been extensively investigated in the last 5 years. The genetic landscape of certain glioma antigens that allow the immune system to discriminate between cancer cells and non-transformed cells remains unclear. In the search for a source of antigens that are able to elicit specific T cell responses against melanoma, the Wölfel, and Rosenberg and Robbins groups initiated interest in tumor neoantigen as therapeutic targets in 2005 (101,102). Using expression-cloning approaches and ex vivo expanded tumor-infiltrating lymphocytes (TILs), the authors described antitumor T cell responses against melanoma antigens that were formed by somatic mutations: Neoantigens. The characterization of neoantigens has made an important contribution to cancer immunology and immunotherapy $(103,104)$ and its understanding in DIPG, for example, may allow a better understanding of the innate and adaptive immune response to markedly improve novel immunotherapies strategies, clinical response rates and, eventually, patient survival. As a result of non-synonymous mutations, neoantigens may be identified using several tools which allow the comparison of DNA isolated from cancer samples with that of normal tissues. cDNA libraries, whole exome sequencing, transcriptome sequencing and MHC-binding prediction are examples (104). A comprehensive list of neoantigens is available at the Immune Epitope Database and Analysis Resource (www.iedb.org). Identifying driver and passenger mutations in GBM using genomic approaches was one of the first studies to be depicted by The Cancer Genome Atlas (cancergenome.nih.gov); however, studies in DIPG are required. These novel tumor-specific antigens may be the key to developing successful cancer therapies (105). An approach known as the cancer exome-based method has been used to determine the $\mathrm{T}$ cell reactivity against neoantigens (106). The success of immune checkpoint blockade, particularly using anti-CTLA-4 and anti-PD-1 in patients with melanoma and lung cancer may be explained by their potential formation of a neoantigen repertoire (107). In fact, it has been demonstrated that melanoma and lung cancer cells have increased mutation rates compared with glioma (108).

Pollack et al (109) evaluated the first clinical vaccination using human leukocyte antigen (HLA)-A2-restricted peptides from Eph receptor A2 (EphA2, a receptor tyrosine kinase 
which in healthy cells regulates the cell growth negatively), IL-13 receptor subunit $\alpha 2$ [IL-13Ra2, a membrane glycoprotein that mediates activation of the transforming growth factor- $\beta 1$ (TGF- $\beta 1$ ) promoter upon stimulation by IL-13 or IL-4 and TNF- $\alpha$ ] and survivin (an apoptosis inhibitor protein) for childhood brain cancer. The GAA peptide vaccination was well-tolerated, and exhibited initial evidence of an immunological and clinical response (109). Pollack et al (110) investigated the protein expression of three glioma-associated antigens in pediatric brain stem glioma and non-brain stem glioma; their results suggested that EphA2, IL-13Ra2 and survivin are reasonable targets for developing vaccines methods for pediatric glioma. Chheda et al (111) provided solid evidence to developing $\mathrm{T}$ cell-based therapy targeting neoantigens in DIPG. The authors identified and investigated a novel HLA-A*02:01-restricted neoantigen (10-mer peptide) containing the H3.3K 27M mutation in DIPG neurospheres, NSC mice bearing intracranial U87H3.3K27M luciferase and donor-derived peripheral blood mononuclear cells (PBMCs). As a result, it was demonstrated: i) that the novel neoantigen was restricted to binding specifically and with a high affinity for HLA-A*02:01, but not for HLA-A*02:02, HLA-A*02:03, HLA-A*02:06, HLA-A*02:07 and HLA-A*02:17; ii) that the neoantigen induced specific $\mathrm{T}$ cell responses in DIPG-derived PBMCs, but not in healthy donors; iii) neoantigen-specific CTL reactivity; and iv) TCR transduction encoding the neoantigen inhibited progression of DIPG in xenograft mice. Ochs et al (112) demonstrated that the vaccination of neoantigen (27-mer peptide) encompassing the H3.3K27M mutation induced a marked Th1 immune response in transgenic mice (112). It has been demonstrated in preclinical models that a potent antitumor immune response, primarily by cytotoxic lymphocytes, is achieved when the combination of immune checkpoint inhibitors including anti-CTLA-4 (ipilimumab) and anti-PD-1 (nivolumab) are administered to markedly mutated types of cancer, including melanoma and lung cancer $(113,114)$. Such evidence together with assumptions about the immunogenic profile of gliomas, the TME, the expression of negative immune checkpoints that lead to inappropriate $\mathrm{T}$ cell activity and the novel neoantigen candidates afford a rationale for improving the immune response by combining immune checkpoint inhibitors and peptide vaccines. In conclusion, this approach may lead the way to personalized immunotherapy. Gubin et al (115) identified that certain tumors are vulnerable to cancer immunotherapy. Using whole exome sequencing/RNA-sequencing and epitope prediction, the authors could identify specific tumor-specific mutations that work as tumor neoantigens (115). Neoantigens are privileged targets for $\mathrm{T}$ cells activated by checkpoint monoclonal antibodies; furthermore, neoantigens may be used in therapeutically effective and personalized cancer vaccines (115). By taking advantage of neoantigen discernments, Ott et al (116) established the feasibility, safety and immunogenicity of a vaccine that targeted 20 predicted personal tumor neoantigens. The vaccination induced marked multi-functional $\mathrm{T}$ cell responses in patients with melanoma; additionally, the vaccine-induced $\mathrm{T}$ cells discriminated mutated from wild-type antigens (116). Of six patients monitored, four had no recurrence at 25 months after vaccination, whereas two with recurrent melanoma were subsequently treated with anti-PD-1 therapy which led to complete tumor regression with neoantigen-specific $\mathrm{T}$ cells. Mutant neoantigens remaining in tumors are favored targets of $\mathrm{T}$ cells reinvigorated by checkpoint blockade therapy. These data offered a strong rationale for further development of this approach, alone and in combination with checkpoint blockade or other immunotherapies (116). The association between neoantigens and DIPG immune response remains unknown.

Zhou et al (117) demonstrated that B7-H3 (CD276), a type I transmembrane glycoprotein, is overexpressed in DIPG samples and the rates of $\mathrm{B} 7-\mathrm{H} 3$ expression were associated with malignancy grade in brainstem gliomas. There is currently no consensus on its biological function in DIPG; however, in several types of cancer, including prostate (118), colon (119), pancreatic (120), renal (121), ovarian (122) and bladder (123) cancer, B7-H3 appears to be responsible for promoting tumor invasion and metastasis.

The ability of immune cells to respond to several tumor antigens and traffic also boosts their attractiveness for the treatment of metastatic cancer. Medulloblastoma, a high-grade (IV) brain cancer, appears to have an immunosuppressive and hostile TME, mainly due to an immunosuppressive profile conferred by M2 macrophages (124). Increased expression of CD1d in a Sonic hedgehog-overexpressing mouse model of medulloblastoma has been demonstrated to be a therapeutic target and may be an exciting alternative for other types of glioma as well (125). The use of CAR-T cells specific to HER2 displayed efficacy against medulloblastoma in a murine model (126).

The antitumor immune reactivity within GBM, but not DIPG, has been investigated and, although there are quantitative antitumor effector cells present within the glioblastoma, these immune cells are non-reactive (127). This fact may be associated with an increased expression of co-inhibitory molecules on $\mathrm{T}$ cells or due to the immunosuppressive microenvironment.

In preclinical studies of GBM, the monotherapy targeting PD-1/PD-L1 and CTLA-4 resulted in long-term survival $(128,129)$. The impact of immune checkpoint on gliomas is currently unmapped, and a better understanding of the pharmacodynamics and immune monitoring effect of immunotherapy on glioma, particularly DIPG, is expected to contribute to the development of this therapeutic approach in children with DIPG. A study by Berghoff et al (130) demonstrated PD-L1 expression in 88\% (103/117) of patients with GBM. The expression of PD-L1 or other inhibitory molecules required to induce marked tumor-induced immune suppression or the level of expression that is associated with a therapeutic response is unknown.

Currently, according to clinicaltrials.org, there are 30 cancer immunotherapy clinical trials ongoing that are targeting GBM (compared with seven clinical trials for DIPG) which may be divided into five major categories: i) Vaccines [cytomegalovirus (CMV) antigen pp65-lysosome-associated membrane protein, mRNA-pulsed dendritic cells, autologous Wilms' tumor 1 (WT1) mRNA-loaded dendritic cells (DCs), tumor lysate-loaded DCs, brain tumor stem cell mRNA-loaded DCs, epitope enhanced peptides corresponding to IL-32Ra2, polyinosinic-polycytidylic acid stabilized with poly-l-lysine and carboxymethylcellulose (poly-ICLC) peptide vaccine, attenuated Listeria monocytogenes encoding EGFR variant III 
(EGFRvIII) and NY-ESO, personalized peptide vaccine plus poly-ICLC/granulocyte/macrophage colony-stimulating factor (GM-CSF) and isocitrate dehydrogenase 1 (IDH1) peptide vaccine]; ii) checkpoint inhibitors (anti-PD-1, anti-LAG-3, anti-IL-15 and anti-CTLA-4); iii) combinations (DC plus T cell adoptive transfer, DC plus anti-PD-1, TGF- $\beta$ receptor I inhibitor plus anti-PD-1, anti-CD27 plus anti-PD-1, anti-PD-L1 plus radiation therapy and anti-PD-1 plus oncolytic adenovirus); iv) adoptive T cell (CAR-T EGFRvIII, CAR-T IL-13Ra2, CAR-T CD133, CMV CAR-T HER2, CMLV CTL T cells, PD-1:CD28 switch receptor); and v) NK donor cells. The knowledge about epitope spreading and further $\mathrm{T}$ cell activation in autoimmune diseases are well-established; however, in brain cancer, these mechanisms require improved elucidation (96). Chongsathidkiet et al (62) suggested in a glioblastoma model that tumor cells present in the central nervous system inhibit $T$ cell migration and induce sequestration of $\mathrm{T}$ cells in the bone marrow. Furthermore, GBM cells are able to stimulate IL-10, arginase-1, indoleamine 2,3-dioxygenase and tryptophan 2,3-dioxygenase responsible for converting monocytes into myeloid-derived suppressor cells (MDSCs) and regulatory T cells (Tregs), and inducing an immunosuppressive microenvironment $(63,96,131)$. Immune checkpoint approaches (antagonists or agonists) may be useful to revert this phenotype in glioma. Regarding DIPG, there are 50 clinical trials ongoing (Table I), but only seven are concerned with immunotherapy approaches: Use of autologous dendritic cells (NCT02840123), H3.3K27M peptide vaccine (NCT02960230), Toll-like receptor agonist (NCT01400672), PegIntron $^{\circledR}$ (PEGylated IFN- $\alpha 2 b$; NCT00036569), anti-PD-1 (NCT01952769 and NCT02359565) and WT1 protein-derived peptide (NCT02750891). Except for NCT00036569, no results for these clinical trials have yet been released. The subsequent Phase II clinical trial tested the cytotoxicity and the efficacy of PegIntron. The study was sponsored by National Cancer Institute and has had 32 patients enrolled (median age, 6.28 years). The primary goal of the study was to evaluate whether there is a difference in the 2-year survival rate of patients treated with radiation alone compared with those patients treated with radiation and followed by PegIntron (132). The 2-year survival rate was not significantly different compared with the other group; however, the time for progression was increased to 7.8 months compared with 5 months in a similar population (132). As a monotherapy, the treatment was not satisfactory, but its use in combination with immune checkpoint blockade or other types of immunotherapy may be effective. Preclinical and immune monitoring studies are required to support the hypothesis that combining immunotherapy and standard treatment or their use as a monotherapy may benefit patients developing DIPG, an orphan type of cancer. Also, analyses involving TME and their ligands, $\mathrm{T}$ cell immune checkpoint profiles (stimulatory/inhibitory) and neoantigens may indicate which patients may respond to a certain type of immunotherapy and may also be used for the rational design of novel immunotherapy approaches. A thorough understanding of the molecular signatures and immunoprofiling as a predictor of patient response to cancer therapy and the use of several tools comprising the next generation of sequencing technologies which allow the understanding of, for example, a range of genes from different immune cell types, the epigenetic changes, the $\mathrm{B}$ and $\mathrm{T}$ cell receptor repertoire. The NanoString approach, whole exome sequencing, protein array, flow cytometry, mass cytometry by time-of-flight (CyTOF), immunohistochemistry (IHC), multiplexed ion beam imaging and systematic evolution of ligands by exponential enrichment have been used to pursue potential biomarkers and contribute to the future of cancer immunotherapy. There is therefore a requirement for studies aimed at DIPG, neoantigens and the TME. Preclinical studies using an orthotopic model or clinical studies, for example, would answer how certain standard therapies including radiotherapy or targeted therapy including HDACi or even combinations with immunotherapy may affect the immune response and the clinical outcomes.

\section{Cancer immunoediting in glioma}

Cancer cells exhibit several mechanisms of avoiding or suppressing the immune response in an attempt to prevent their destruction and consequently providing for their development and progression (15). This process is known as cancer immunoediting and comprises a well-established and co-ordinated subsequent process known as elimination, equilibrium and escape $(16,17)$. In the last phase, transformed variant cells selected in the equilibrium phase undergo clonal growth in an immunologically regulated environment characterized mainly by the decrease in co-stimulatory molecules (18), antigen loss due to the downregulation of MHC molecules (133), resistance to apoptosis $(19,134)$, the augmentation of $\mathrm{CD}^{+}{ }^{+} \mathrm{CD} 25^{+}$ forkhead box P3 (FoxP3) ${ }^{+}$Tregs (135), IL-10-secreting $\mathrm{T}$ cells (136), M2 macrophages (137), MDSCs (138) and the increase in the expression of $\mathrm{T}$ cell-inhibitory molecules (immune exhaustion markers) including PD-1, PD-L1, PD-L2, CTLA-4, LAG-3, TIM-3, VISTA and galectin-9 $(141,142)$.

The presence of several inhibitory immune checkpoints that block $\mathrm{T}$ cell responses and stimulate $\mathrm{T}$ cell responses offers particular strategies for mobilizing the immune system to attack cancer cells (139). CTLA-4 and PD-1 are strategic receptors on activated $\mathrm{T}$ cells that mediate immunosuppression in cancer. In the first case, CTLA- 4 on the T cells binds to two ligands on antigen-presenting cells (CD80 and CD86), the same ligands required for CD28 activation. Owing to the higher affinity for both ligands, CTLA-4 is a competitive inhibitor for T cell activation (140). In the second case, PD-L1 and PD-L2, present on cancer cells or stromal cells interact with PD-1 receptor causing a downregulation of T cell responses (141). The immune checkpoint blockade mediated by anti-CTLA-4 and anti-PD-1 monoclonal antibodies remains to be elucidated (142). Immunotherapy with immune checkpoint inhibitors in certain types of cancer has revealed significant success in the last decade (143-146). Despite the accomplishments of these therapies, not every patient responds to immune checkpoint blockade and even the responders often experience toxic effects. Furthermore, there is an increasing requirement to identify potential biomarkers, primarily in immune cells, which may predict whether the patient with cancer may or may not respond to a particular immunotherapy, including immune checkpoint blockade or immune checkpoint agonist. Several clinical trials regarding immune checkpoint blockade are ongoing in glioblastoma and other types of brain cancer, but are required to be performed in DIPG. 
Table I. Ongoing clinical trials in patients with diffuse intrinsic pontine glioma according to clincialtrials.gov.

\begin{tabular}{|c|c|c|c|c|}
\hline Identifier & Status & Study results & Phase & Study type \\
\hline NCT03101813 & Recruiting & None available & NA & Observational \\
\hline NCT01688401 & Suspended & None available & Phase I & Interventional \\
\hline NCT02420613 & Recruiting & None available & Phase I & Interventional \\
\hline NCT02233049 & Recruiting & None available & Phase II & Interventional \\
\hline NCT02992015 & Recruiting & None available & Early Phase I & Interventional \\
\hline NCT01182350 & Active, not recruiting & None available & Phase II & Interventional \\
\hline NCT01165333 & Completed & None available & Phase I & Interventional \\
\hline NCT00996723 & Completed & None available & Phase I & Interventional \\
\hline NCT01777633 & Completed & None available & Phase I/Phase II & Interventional \\
\hline NCT01400672 & Completed & None available & Phase I & Interventional \\
\hline NCT01106794 & Recruiting & None available & NA & Observational \\
\hline NCT01393912 & Completed & None available & Phase I & Interventional \\
\hline NCT00890786 & Active, not recruiting & None available & Early Phase I & Interventional \\
\hline NCT03086616 & Recruiting & None available & Phase I & Interventional \\
\hline NCT02840123 & Recruiting & None available & Phase I & Interventional \\
\hline NCT01222754 & Active, not recruiting & None available & Phase I & Interventional \\
\hline NCT03126266 & Not yet recruiting & None available & NA & Interventional \\
\hline NCT00036569 & Completed & Available & Phase II & Interventional \\
\hline NCT02960230 & Recruiting & None available & Phase I & Interventional \\
\hline NCT02717455 & Recruiting & None available & Phase I & Interventional \\
\hline NCT03178032 & Recruiting & None available & Phase I & Interventional \\
\hline NCT00600054 & Completed & None available & Phase II & Interventional \\
\hline NCT01922076 & Recruiting & None available & Phase I & Interventional \\
\hline NCT01517776 & Terminated & None available & Phase II & Interventional \\
\hline NCT02274987 & Recruiting & None available & NA & Interventional \\
\hline NCT01952769 & Active, not recruiting & None available & Phase I/Phase II & Interventional \\
\hline NCT02758366 & Recruiting & None available & Phase II & Interventional \\
\hline NCT01644773 & Recruiting & None available & Phase I & Interventional \\
\hline NCT01058850 & Terminated & None available & Phase I & Interventional \\
\hline NCT01189266 & Active, not recruiting & None available & Phase I/Phase II & Interventional \\
\hline NCT02750891 & Active, not recruiting & None available & Phase I/Phase II & Interventional \\
\hline NCT02359565 & Recruiting & None available & Phase I & Interventional \\
\hline NCT03243461 & Not yet recruiting & None available & Phase III & Interventional \\
\hline NCT02607124 & Recruiting & None available & Phase I/Phase II & Interventional \\
\hline NCT01469247 & Active, not recruiting & None available & Phase I/Phase II & Interventional \\
\hline NCT02644460 & Recruiting & None available & Phase I & Interventional \\
\hline NCT00879437 & Active, not recruiting & None available & Phase II & Interventional \\
\hline NCT00028795 & Completed & None available & Phase II & Interventional \\
\hline NCT00278278 & Unknown & None available & Phase III & Interventional \\
\hline NCT01836549 & Completed & None available & Phase II & Interventional \\
\hline NCT02742883 & Active, not recruiting & None available & Phase II & Interventional \\
\hline NCT01445288 & Recruiting & None available & NA & Observational \\
\hline NCT01837862 & Recruiting & None available & Phase I/Phase II & Interventional \\
\hline NCT01884740 & Recruiting & None available & Phase I/Phase II & Interventional \\
\hline NCT02444546 & Recruiting & None available & Phase I & Interventional \\
\hline NCT00561691 & Completed & None available & Phase III & Observational \\
\hline NCT01878266 & Recruiting & None available & Phase III & Interventional \\
\hline NCT02644291 & Recruiting & None available & Phase I & Interventional \\
\hline NCT01502917 & Recruiting & None available & Phase I & Interventional \\
\hline NCT02343406 & Recruiting & None available & Phase II & Interventional \\
\hline
\end{tabular}


Table II. Selected markers and approaches which may be used in cancer or peripheral blood mononuclear cells for immunomonitoring in diffuse intrinsic pontine glioma.

\begin{tabular}{|c|c|c|c|c|}
\hline Mass cytometry & Flow cytometry & Immunohistochemistry & $\begin{array}{l}\text { Imaging mass } \\
\text { cytometry }\end{array}$ & NanoString \\
\hline $\begin{array}{l}\text { CD68, PD-L1, VISTA, } \\
\text { CD70, CD73, FoxP3, } \\
\text { BTLA, 4-1BBL, ICOSL, } \\
\text { CD80, B7-H4, CTLA-4, } \\
\text { CD3, TIM-3, CD27, CD86, } \\
\text { PD-1, CD28, KI67, 4-1BB, } \\
\text { TIGIT, CD4, CD8, OX40, } \\
\text { CD326, ICOS, LAG-3, } \\
\text { CD11c, CD11b, CD44, } \\
\text { CD62L, galectin-9, } \\
\text { galectin-1,galectin-3, } \\
\text { NY-ESO1, HVEM, } \\
\text { B7-H3, CD45, GITR, } \\
\text { PD-L2, OX40L, } \\
\text { HLA-DR and CD56 }\end{array}$ & $\begin{array}{l}\text { CD4, CD8, ICOS, FoxP3, } \\
\text { PD-1, 4-1BB, OX40, } \\
\text { CTLA-4, CD14, CD16, } \\
\text { CD56, CD69, NKp44, } \\
\text { NKp30, NKG2A, NKG2C, } \\
\text { NKG2D, PD-L1, Eomes, } \\
\text { T-bet, Blimp-1, Bcl-6, } \\
\text { c-Myc, CCR7, CD45RA, } \\
\text { CD45RO, ROR-y } \\
\text { and VISTA }\end{array}$ & $\begin{array}{l}\text { H3K27M mutant, } \\
\text { GFAP, human nestin, } \\
\text { Olig2, Ki67 } \\
\text { human vimentin, } \\
\text { CD4, CD8, } \\
\text { CD45RO, GrB, } \\
\text { ICOS, CD68, } \\
\text { PD-L1, PD-1, } \\
\text { arginase-1, iNOS } \\
\text { and VISTA }\end{array}$ & $\begin{array}{l}\text { CD31, CD68, CD3, } \\
\text { CD4, CD8, CD45, } \\
\text { actin, } \beta \text {-catenin, } \\
\text { nestin, PDGFRA, } \\
\text { ACVR1, FGFR1, } \\
\alpha \text {-SMA, histone H3, } \\
\text { histone K27M mutant, } \\
\text { CD44, c-Myc, VISTA, } \\
\text { vimentin, EGFR III, } \\
\text { CD133, galectin 1, } \\
\text { galectin 3, FoxP3, } \\
\text { CD25, PD-1, } \\
\text { PD-L1, p53 } \\
\text { and SHP2 }\end{array}$ & $\begin{array}{l}\text { CSAG2, MAGEA3, } \\
\text { MAGEC2,IL13RA2, } \\
\text { PRAME, CSPG4 } \\
\text { and SOX10, } \\
\text { CD45RO, CD20, } \\
\text { CD57, FoxP3 } \\
\text { and granzyme B }\end{array}$ \\
\hline
\end{tabular}

Data taken from $(103,191-215,217-226)$.

The concept of cancer immunoediting has been explored in many types of tumor, but only recently has attention turned to glioma. Efforts have been made to understand how the immune system is able to support the glioma cancer cells to develop and grow, and at the same time dampen an antitumor immune response. Numerous antigens from glioma have been described, including IL-13Ra2 $(109,111,147,148)$, $\mathrm{N}$-acetyl- $\beta$-glucosamine (149), sex-determining region $\mathrm{Y}$ box (SOX)2 (150,151), EGFRvIII (152), SOX6 (153), gliomaexpressed antigen 1/2 (154), paired helical filament 3 (154), NK group 2D (NKG2D), NKp30, MHC class I polypeptiderelated sequence A/B (MICA/B) $(155,156)$, UL16-binding protein 1 (157), EphA2 (109,110), EphB6 (158), antigen isolated from immunoselected melanoma-2 (159), squamous cell carcinoma antigen recognized by $\mathrm{T}$ cells $1 / 3(160,161)$, HER2 (162), tyrosinase-related protein $2(163,164)$, glycoprotein 100 (165), melanoma antigen-1 (166) and NY-ESO1 (167). Potential mechanisms in glioma immunoediting include evasion of adaptive $\mathrm{T}$ cell responses by altering the MHC class I antigen processing/presentation and a decrease in levels of cell-surface MHC I (168), antigen loss (169), a decrease in $\beta 2$-microglobulin (170), latent membrane protein 2 , transporter associated with antigen processing 1 and B7 expression (171), upregulation of B7-H3, impairing NK cell recognition by releasing NKG2D ligands $(172,173)$ and increasing the expression of HLA-E and HLA-G, and, in certain cases, MHC class I expression $(172,174)$ and increasing the immunosuppressive profile conferred by TGF- $\beta$, IL-10, prostaglandin $\mathrm{E}_{2}$ and Treg promotion (175-178). Understanding the glioma immunoediting process will assist in unraveling the mechanisms in DIPG which abrogate an effector immune response. Unfortunately, all these mechanisms in DIPG are currently unknown.
Cancer immunoediting decreases the immunogenicity of developing tumors and supports tumor development. Therefore, immune monitoring studies have the potential to reveal the immunological machinery of antitumor responses, evaluate disease progression, assess the therapeutic effect, describe and identify novel candidates for immunotherapy, and act as predictive and correlative markers of clinical outcome.

\section{Immune monitoring approaches to DIPG}

To obtain an improved understanding of the DIPG microenvironment and the use of immune checkpoint approaches which may benefit a robust immune response against DIPG cancer cells, it would be interesting to conduct immune monitoring studies in patients with cancer, or an orthotopic mouse model for developing DIPG (Table II). As aforementioned, the immune checkpoint blockade is minimal in those tumors that have few somatic mutations and consequently poor neoantigen repertoire. Several studies have demonstrated that even by using immune checkpoint blockade including anti-CTLA-4 and anti-PD-1, several negative immune checkpoint molecules on T cells (TIM-3, LAG-3, VISTA, TIGIT and BTLA) are overexpressed, acting to dampen the immune activation in an attempt to achieve the immune homeostasis (179-190). These results were only possible due to the design of several immune monitoring approaches in the genomics and proteomics field. In a number of types of human cancer, the expression of immune checkpoints has been associated with a good or poor outcome. However, given the lack of clarity, the present review endorses the importance of immune monitoring studies in DIPG. Studies regarding immune monitoring approaches to DIPG have the potential to elucidate immunological mechanisms of antitumor responses, evaluate the therapeutic effect, 
monitor disease progression, serve as a prognostic marker of clinical and outcome and also identify potential candidates for cancer immunotherapy. Immunological responses may be determined by alterations in $\mathrm{T}$ cell infiltrate and the quality of $\mathrm{T}$ cells regarding co-stimulatory/co-inhibitory molecules, the ratio of $\mathrm{CD}^{+} / \mathrm{CD}^{+}$Tregs, cytokine production (inflammatory or immunosuppressive profile), the presence and macrophage differentiation (type 1 or type 2 macrophages), the expression of certain trivial tumor ligands including PD-L1, PD-L2, B7-H3, B7-H4, MICA/B and myeloid C-type lectin receptors. Blood and tissue samples may be analyzed to evaluate specific types of neoantigen or gene that may activate a robust immune response in DIPG. Furthermore, neoantigen-specific T cells may be assessed for immunogenicity using enzyme-linked immunospot (ELISPOT) and tetramer analysis. Overall, the immune monitoring profile from preclinical/clinical blood and tissue samples is the best way to assess and characterize the quality of immune response from those patients who are undergoing several therapeutic approaches. Studies which aim to estimate the impact of several therapies on $\mathrm{T}$ cell responses to DIPG neoantigens in tumor samples and to investigate the association between $\mathrm{T}$ cell neoantigen responses and other immunological parameters to drug-associated toxicity and radiographical responses would be interesting to investigate certain biomarker candidates in patients developing DIPG.

The increased availability of tissue samples for preclinical investigation, the development of novel experimental model systems, the advent of next-generation sequencing, IHC, flow cytometry and CyTOF provide useful tools to monitor the future of immunotherapy. Immune monitoring studies as proposed in the present study would benefit a better understanding of whether several types of immunotherapy and combinations are able to restore the quality of antitumor responses in DIPG. Serum cytokines, angiogenic factors and chemokines should also be evaluated using ELISPOT, ELISA or other relevant multiplex-based protein assay methods. Comprehensive analysis in immune profiles may lead to the identification of immune-based biomarkers.

The preclinical approaches may provide the opportunity to investigate in depth the effects of cancer immunotherapy and its possible use of adoptive transfer strategies including $\mathrm{CD}^{+}$, CAR-T cells, NK cells, immune checkpoints and drug delivery on gliomas. So, the primary goal of performing immune monitoring studies in DIPG specimens is to determine an immunological profile in PBMCs and the potential changes in tumor samples (tumor ligands and TME) in an attempt to understand the TME and also the systemic immune response. The establishment of immunological biomarkers may promote the development of practical immunotherapeutic approaches. To determine the adaptive immune signatures in the TME at the baseline and during the course of the treatment using the immune checkpoint blockade combination (anti-CTLA-4 and anti-PD-1), Chen et al (66) performed, using melanoma tissue samples, an immune profiling study by analyzing a 12-marker IHC panel and gene expression pertaining to common cancer signaling pathways using the NanoString approach. By comparing responders and non-responders during the CTLA-4 and anti-PD-1 blockade, it was demonstrated that, at baseline, no change was observed in any of the biomarkers measured, including CD45RO, CD20, CD57, CD68, FoxP3, granzyme B,
PD-1, LAG-3, CD14, CD33, CD163 and CD206. However, there was a significantly increased density of $\mathrm{CD}^{+} \mathrm{T}$ cells in responders compared with in non-responders during the treatment. Additionally, increased expression of CD45RO, CD20, CD57, FoxP3 and granzyme $\mathrm{B}$ was detected in responders compared with in non-responders. Together, these results are relevant in the prediction of biomarkers of response and resistance to the immune checkpoint blockade, while offering a mechanistic understanding of immune checkpoint blockade as associated with enhanced cytotoxic activity, antigen processing and the IFN- $\gamma$ signaling pathway. In another study using the NanoString approach, Beard et al (191) investigated the potential candidates for immunotherapy by comparing the gene signatures between melanoma and healthy tissue. In melanoma samples, chondrosarcoma-associated gene 2/3 protein, melanoma-associated antigen A3 (MAGEA3), melanoma-associated antigen C2 (MAGEC2), IL-13Ra2, preferentially expressed antigen in melanoma, chondroitin sulfate proteoglycan 4 and SOX10 were overexpressed when compared with the healthy tissue (169).

In glioma cancer, the NanoString approach has been used extensively to identify driver genes as potential therapeutic targets and also to predict signature disease specific-survival and recurrence-free survival times (192-206). However, there is an evident lack of studies involving patients with DIPG.

The significance of an integral immune surveillance in controlling cancer progression and development has been known for a number of years. Several studies have demonstrated a marked association between TILs in cancer tissue and favorable prognosis in numerous malignancies $(85,207-209)$. $\mathrm{CD}^{+}$ $\mathrm{T}$ cells and the ratio of $\mathrm{CD}^{+}$effector/FoxP3 ${ }^{+}$Tregs appears to be associated with improved prognosis and long-term survival in a number of solid tumors. CyTOF has been used to define immune cell populations, to identify potential biomarkers and in drug development (210). By measuring 34 parameters simultaneously in single cells, Bendall et al (211) defined the hematopoietic hierarchy from healthy human bone marrow. Spitzer et al (212) analyzed the immune responses in several tissues following anti-PD-1 and PD-L1 immunotherapy by developing intuitive models (Scaffold map) to visualize single cell data with statistical implication (212). In their study, the authors were able to demonstrate the crucial involvement of the systemic immune response in cancer rejection. Wei et al (213) performed a comprehensive profile on the effects of checkpoint blockade (anti-CTLA-4 and anti-PD-1) on the tumor immune infiltrate in humans and mice. It was demonstrated that the tumor-infiltrating $\mathrm{T}$ cells were markedly similar between tumor models, but there were differences in the subsets of tumorinfiltrating $\mathrm{T}$ cell populations; whereas the anti-PD-1 therapy induced the expansion of exhausted $\mathrm{CD}^{+} \mathrm{T}$ cells, anti-CTLA-4 induced the expansion of the Th1-like $\mathrm{CD}^{+}{ }^{+}$effector cell population. In a phase II clinical trial designed to determine the efficacy of metronomic temozolomide in recurrent glioblastoma patients, Omuro et al (214) determined, using mass spectrometry genotyping/iPLEX ${ }^{\circledR}$, tissue from 38 patients ( 28 glioblastomas and 10 grade III), the presence of certain mutations previously described in glioma. Mutations were identified in EGFR (EGFR_P596L, EGFR_C620Y, EGFR_G598V, EGFR_I91L, EGFR_T263P and EGFR_V651M), IDH1 (IDH1_R132L_H and R_132C_G_S) and ERBB2 (ERBB2_L49H) (214). 
Together, these results provided substantial insights that CyTOF and the tools available for high-dimensional analysis, including Scaffold, SPADE, viSNE and CITRUS, offer a feasible way of correlating and predicting immune biomarkers, which has not yet not been performed in DIPG.

\section{Conclusions}

The present review makes a claim for the importance of immune monitoring studies in DIPG, an incurable brain cancer representing the principal cause of mortality from pediatric brain tumors. Growing diffusely in the ventral pons, the tumor causes disabling neurological symptoms that gradually abolish the co-ordination of the face, pharynx and body. Unfortunately, surgical resection is not a feasible option, radiation therapy results only in temporary stabilization of symptoms, and several chemotherapy trials developed for adult glioma have not demonstrated satisfactory results to date (215). Novel and useful therapies are urgently required, and immunotherapy may be an excellent strategy to modulate the immune response to this devastating disease. Several immune checkpoint molecules have been proposed in the present review as having an involvement in a potential strategy for mobilizing the immune system for the treatment of DIPG. Also, by sharing the recent achievements in other types of cancer, the present review may serve to stimulate the scientific community in developing preclinical and clinical immune monitoring studies in DIPG. An improved understanding regarding TME, cancer immunoediting and neoantigens is required.

Randomized clinical trials have allowed the advance of a consistent evidence-based medicine. Currently, several tools may be used to characterize the biology of several types of cancer, and the present review highlights the requirement for designing more descriptive clinical trials which are expected to result in more marked treatment effects for a more significant portion of treated patients. In the present review, certain immunological landscape approaches including flow cytometry, CyTOF, IHC and imaging mass cytometry, as well as certain biomarker candidates, were proposed as potential approaches that may be useful to perform immune monitoring studies in tissue and PBMCs from patients developing DIPG. It is therefore clear that molecular tools which allow the identification of i) alterations at the genomic level (DNA/RNA) including single-nucleotide variations, insertion/deletion, loss of heterozygosity and translocation; ii) epigenomic modifications including DNA methylation (CpG islands), DNA methylation (non-CpG islands) and histone modification (acetylation or methylation); and iii) protein expression, post-translational modification, and protein complexes and interactions (whole exosome sequencing, whole genome sequencing and bisulfite sequencing), as well as targeted identification (multiple reaction monitoring) are essential to detect, diagnose, monitor, estimate and predict therapeutic interventions likely to benefit the patient (216). As the immune system is a multifaceted cellular system that is not entirely understood, particularly in the cancer microenvironment, the importance of monitoring the immune responses from those patients undergoing several treatment approaches has become crucial for understanding the cancer biology and potential biomarkers and also for designing new drugs. Several activating receptors on $\mathrm{T}$ cells including
CD27, CD28, OX40, 4-1BB, CD40 ligand, DNAX-accessory molecule 1, transmembrane activator and calcium modulator and cyclophilin ligand-interactor, B cell maturation antigen, ICOS, GITR, B cell-activating factor belonging to the TNF family receptor, and inhibitory receptors including CTLA-4, PD-1, PD-L1, CD160, CD200 receptor, LAG-3, 2B4, TNF superfamily member 14, BTLA, VISTA, TIGIT, B7-H3, B7-H4 and killer cell lectin-like receptor subfamily $\mathrm{G}$ member 1 have been used to design agonists or antagonists, respectively, as immune checkpoint targets to improve immune responses against several types of cancer. The robust clinical responses, but not universally, in a diverse group of advanced cancer suggest that immune checkpoint immunotherapy may be also be beneficial in the treatment of DIPG. Assuming that in the glioblastoma, numerous infiltrating Tregs and high levels of immune-suppressive cytokines dictate the immune suppression, the $\mathrm{T}$ cell exhaustion profile and also the potential neoantigens in DIPG should be considered. In the present review, the idea of immune monitoring approaches has been discussed, and the use of antagonists or agonists as immune checkpoint approaches for the treatment of DIPG are also supported. The recognition that the immune response is dysfunctional in patients with cancer and also the current immune checkpoint strategies including agonists/antagonists have prompted certain questions regarding why only certain patients with cancer exhibit marked responses or how the efficacy, specificity and safety of cancer immunotherapy strategies may be increased, or what would be the best model system and biomarkers to address these questions. Monoclonal antibodies that block PD-1 and CTLA-4 proteins further exemplified the power of cytotoxic T lymphocytes in the control of tumor development by reversing cancer-induced immunosuppression and inducing durable therapeutic responses in certain patients with cancer. Immune checkpoint therapy targeting co-inhibitory or co-stimulatory molecules on T cells is a new paradigm for cancer treatment. Rather than targeting the tumor cell, this approach targets molecules on immune cells that regulate their activity to sustain immune responses to cancer and achieve elimination of tumors and immunity to recurrence. This strategy has proven effective in treating different types of cancer and is now the standard of care for metastatic melanoma and lung cancer. The high-dimensional analysis of tissue and blood samples from patients with cancer is being performed with several technologies and different software. Examples of these technologies are flow cytometry and CyTOF; the analyses are made using specific software including FlowJo, viSNE, SPADE, Scaffold and CITRUS.

In conclusion, substantial improvement has been made in the development of cancer immunotherapy. Immune monitoring studies have identified certain biomarkers which are able to reveal the complexity of the cancer microenvironment (217-226). The novel way of thinking and managing patients with cancer under immunotherapy perspectives by inducing the immune system to track down and destroy cancer cells it is not hyperbole, but rather a reality. Patients with only weeks or months to live are now surviving for years following treatment. Personalized cancer immunotherapies targeting tumor-specific mutant neoantigens are leading to combinatorial therapies, where several strategies act to kill cancer cells. Such effects have been accomplished in preclinical tumor 
models and can now be extended to human patients with cancer including DIPG.

\section{Acknowledgements}

The present review reflects an extension of a project for the Emperor Science Award 2017 sponsored by Stand Up To Cancer on which I was the mentor. I thank Brandon Dominy from Lexington High School, Lexington, TX, USA, the student involved in this project.

\section{Funding}

No funding was received.

\section{Availability of data and materials}

Not applicable.

\section{Author's contribution}

JABS was responsible for the conception and design of the review article, manuscript writing, and reviewing and editing.

\section{Ethics approval and consent to participate}

Not applicable.

\section{Consent for publication}

Not applicable.

\section{Competing interests}

The author declares that he has no competing interests.

\section{References}

1. Mukherjee S: The Emperor of All Maladies. Scribner publisher, 2010.

2. National Cancer Institute (NCI): https://www.cancer.gov.

3. Willers H, Azzoli CG, Santivasi WL and Xia F: Basic mechanisms of therapeutic resistance to radiation and chemotherapy in lung cancer. Cancer J 19: 200-207, 2013.

4. Barker HE, Paget JT, Khan AA and Harrington KJ: The tumour microenvironment after radiotherapy: Mechanisms of resistance and recurrence. Nat Rev Cancer 15: 409-425, 2015.

5. Alfarouk KO, Stock CM, Taylor S, Walsh M, Muddathir AK, Verduzco D, Bashir AH, Mohammed OY, Elhassan GO, Harguindey S, et al: Resistance to cancer chemotherapy: failure in drug response from ADME to P-gp. Cancer Cell Int 15: 71, 2015.

6. Raguz S and Yagüe E: Resistance to chemotherapy: New treatments and novel insights into an old problem. Br J Cancer 99: 387-391, 2008

7. Tsuruo T, Naito M, Tomida A, Fujita N, Mashima T, Sakamoto H and Haga N: Molecular targeting therapy of cancer: Drug resistance, apoptosis and survival signal. Cancer Sci 94: 15-21, 2003.

8. Hanahan D and Weinberg RA: The hallmarks of cancer. Cell 100: $57-70,2000$.

9. Hanahan D and Weinberg RA: The hallmarks of cancer: The next generation. Cell 5: 646-674, 2011.

10. Lee S and Margolin K: Cytokines in cancer immunotherapy. Cancers (Basel) 3: 3856-3893, 2011.

11. Levitzki A and Klein S: Signal transduction therapy of cancer. Mol Aspects Med 31: 287-329, 2010.
12. Lawler SE, Speranza MC, Cho CF and Chiocca EA: Oncolytic viruses in cancer treatment: A Review. JAMA Oncol 3: 841-849, 2017.

13. Rajabi M and Mousa SA: The role of angiogenesis in cancer treatment. Biomedicines 5: E34, 2017.

14. Shankaran V, Ikeda H, Bruce AT, White JM, Swanson PE, Old LJ and Schreiber RD: IFN-gamma and lymphocytes prevent primary tumour development and shape tumour immunogenicity. Nature 410: 1107-1111, 2001.

15. Dunn GP, Bruce AT, Ikeda H, Old LJ and Schreiber RD: Cancer immunoediting: From immunosurveillance to tumor escape. Nat Immunol 3: 991-998, 2002.

16. Mittal D, Gubin MM, Schreiber RD and Smyth MJ: New insights into cancer immunoediting and its three component phases elimination, equilibrium and escape. Curr Opin Immunol 27: 16-25, 2014.

17. Vesely MD and Schreiber RD: Cancer immunoediting: Antigens, mechanisms, and implications to cancer immunotherapy. Ann NY Acad Sci 1284: 1-5, 2013.

18. Dunn GP, Old LJ and Schreiber RD: The three Es of cancer immunoediting. Annu Rev Immunol 22: 329-360, 2004.

19. Dunn GP, Koebel CM and Schreiber RD: Interferons, immunity and cancer immunoediting. Nat Rev Immunol 6: 836-848, 2006.

20. Baxevanis CN, Perez SA and Papamichail M: Cancer immunotherapy. Crit Rev Clin Lab Sci 46: 167-189, 2009.

21. Cancer Research Institute (CRI): https://www.cancerresearch.org

22. Immunotherapy MD Anderson Cancer Center (MDACC) https:// www.mdanderson.org/treatment-options/immunotherapy.html.

23. Sathyanarayanan V and Neelapu SS: Cancer immunotherapy: Strategies for personalization and combinatorial approaches. Mol Oncol 9: 2043-2053, 2015.

24. Farkona S, Diamandis EP and Blasutig IM: Cancer immunotherapy: The beginning of the end of cancer? BMC Med 14: 73 2016.

25. Immunotherapy strategies. Extracted from Society for Immunotherapy for Cancer.

26. Newick K, O'Brien S, Moon E and Albelda SM: CAR T cell therapy for solid tumors. Annu Rev Med 68: 139-152, 2017.

27. Romero D: Immunotherapy: A CAR T-cell recipe for success. Nat Rev Clin Oncol 14: 330, 2017.

28. Couzin-Frankel J: Breakthrough of the year 2013. Cancer immunotherapy. Science 342: 1432-1433, 2013.

29. Buchbinder EI and Desai A: CTLA-4 and PD-1 Pathways: Similarities, differences, and implications of their inhibition. Am J Clin Oncol 39: 98-106, 2016.

30. Leach DR, Krummel MF and Allison JP: Enhancement of antitumor immunity by CTLA-4 blockade. Science 271: 1734-1736, 1996

31. Tivol EA, Borriello F, Schweitzer AN, Lynch WP, Bluestone JA and Sharpe AH: Loss of CTLA-4 leads to massive lymphoproliferation and fatal multiorgan tissue destruction, revealing a critical negative regulatory role of CTLA-4. Immunity 3: 541-547, 1995.

32. Waterhouse P, Penninger JM, Timms E, Wakeham A, Shahinian A, Lee KP, Thompson CB, Griesser H and Mak TW: Lymphoproliferative disorders with early lethality in mice deficient in Ctla-4. Science 270: 985-988, 1995.

33. Curran MA, Montalvo W, Yagita $\mathrm{H}$ and Allison JP: PD-1 and CTLA-4 combination blockade expands infiltrating T cells and reduces regulatory $\mathrm{T}$ and myeloid cells within B16 melanoma tumors. Proc Natl Acad Sci USA 107: 4275-4280, 2010.

34. Selby MJ, Engelhardt JJ, Quigley M, Henning KA, Chen T, Srinivasan M and Korman AJ: Anti-CTLA-4 antibodies of IgG2a isotype enhance antitumor activity through reduction of intratumoral regulatory T cells. Cancer Immunol Res 1: 32-42, 2013.

35. Thomas LJ, He LZ, Marsh $\mathrm{H}$ and Keler T: Targeting human CD27 with an agonist antibody stimulates T-cell activation and antitumor immunity. Oncoimmunology 3: e27255, 2014.

36. He LZ, Prostak N, Thomas LJ, Vitale L, Weidlick J, Crocker A, Pilsmaker CD, Round SM, Tutt A, Glennie MJ, et al: Agonist anti-human CD27 monoclonal antibody induces $\mathrm{T}$ cell activation and tumor immunity in human CD27-transgenic mice. J Immunol 191: 4174-4183, 2013.

37. Emens LA, Butterfield LH, Hodi FS Jr, Marincola FM and Kaufman HL: Cancer immunotherapy trials: Leading a paradigm shift in drug development. J Immunother Cancer 4: 42, 2016.

38. Bartkowiak T and Curran MA: 4-1BB agonists: Multi-potent potentiators of tumor immunity. Front Oncol 5: 117, 2015.

39. Chester C, Ambulkar S and Kohrt HE: 4-1BB agonism: Adding the accelerator to cancer immunotherapy. Cancer Immunol Immunother 65: 1243-1248, 2016. 
40. Bartkowiak T, Singh S, Yang G, Galvan G, Haria D, Ai M Allison JP, Sastry KJ and Curran MA: Unique potential of 4-1BB agonist antibody to promote durable regression of $\mathrm{HPV}^{+}$tumors when combined with an E6/E7 peptide vaccine. Proc Natl Acad Sci USA 112: E5290-E5299, 2015.

41. Knee DA, Hewes B and Brogdon JL: Rationale for anti-GITR cancer immunotherapy. Eur J Cancer 67: 1-10, 2016.

42. Linch SN, McNamara MJ and Redmond WL: OX40 agonists and combination immunotherapy: Putting the pedal to the metal Front Oncol 5: 34, 2015.

43. Lipson EJ and Drake CG: Ipilimumab: An anti-CTLA-4 antibody for metastatic melanoma. Clin Cancer Res 17: 6958-6962, 2011.

44. Hellman MD, Ott PA, Zugazagoitia J, Ready NE, Hann CL and De Braud FG: Nivolumab (Nivo) + Ipilimumab (Ipi) in advanced small-cell lung cancer (SCLC): First report of a randomized expansion cohort from checkmate 032. J Clin Oncol 35: 8503, 2017.

45. Govindan R, Szczesna A, Ahn MJ, Schneider CP, Gonzalez Mella PF, Barlesi F, Han B, Ganea DE, Von Pawel J, Vladimirov V, et al: Phase III trial of ipilimumab combined with paclitaxel and carboplatin in advanced squamous non-small-cell lung cancer. J Clin Oncol 35: 3449-3457, 2017.

46. Relationship Between Tumor Mutation Burden and Predicted Neo-antigen Burden in Patients With Advanced Melanoma or Bladder Cancer Treated With Nivolumab or Nivolumab Plus Ipilimumab (CA209-260). NCT:02553642. Available at Clinical Trial.gov.

47. Neo-Adjuvant Bladder Urothelial Carcinoma COmbinationimmunotherapy (NABUCCO. NCT:03387761). Available at Clinical Trial.gov.

48. Ipilimumab + Androgen Deprivation Therapy in Prostate Cancer. NCT:01377389. Available at Clinical Trial.gov.

49. Reddy SM, Amaria RN and Spencer CN: Neoadjuvant nivolumab versus combination ipilimumab and nivolumab followed by adjuvant nivolumab in patients with resectable stage III and oligometastatic stage IV melanoma: Preliminary findings. Presented at: 32nd SITC Annual Meeting; Nov 8-12, 2017; National Harbor, MD. Abstract O15.

50. Mazza C, Escudier B and Albiges L: Nivolumab in renal cell carcinoma: Latest evidence and clinical potential. Ther Adv Med Oncol 9: 171-181, 2017.

51. Sorensen SF, Zhou W, Dolled-Filhart M, Georgsen JB, Wang Z, Emancipator K, Wu D, Busch-Sørensen M, Meldgaard P and Hager H: PD-L1 expression and survival among patients with advanced non-small cell lung cancer treated with chemotherapy. Transl Oncol 9: 64-69, 2016.

52. Sheng Z, Zhu X, Sun Y and Zhang Y: The efficacy of anti-PD-1/PD-L1 therapy and its comparison with EGFR-TKIs for advanced non-small-cell lung cancer. Oncotarget 8: 57826-57835, 2017.

53. Byun DJ, Wolchok JD, Rosenberg LM and Girotra M: Cancer immunotherapy - immune checkpoint blockade and associated endocrinopathies. Nat Rev Endocrinol 13: 195-207, 2017.

54. Immunotherapy strategies. Extracted from Society for Immunotherapy for Cancer, https://www.sitcancer.org/home

55. Goc J, Germain C, Vo-Bourgais TK, Lupo A, Klein C, Knockaert S, de Chaisemartin L, Ouakrim H, Becht E, Alifano M, et al: Dendritic cells in tumor-associated tertiary lymphoid structures signal a Th1 cytotoxic immune contexture and license the positive prognostic value of infiltrating CD8 T cells. Cancer Res 74: 705-715, 2014

56. Scott DW, Chan FC, Hong F, Rogic S, Tan KL, Meissner B, Ben-Neriah S, Boyle M, Kridel R, Telenius A, et al: Gene expression-based model using formalin-fixed paraffin-embedded biopsies predicts overall survival in advanced-stage classical Hodgkin lymphoma. J Clin Oncol 31: 692-700, 2013.

57. Muris JJ, Meijer CJ, Cillessen SA, Vos W, Kummer JA, Bladergroen BA, Bogman MJ, MacKenzie MA, Jiwa NM, Siegenbeek van Heukelom LH, et al: Prognostic significance of activated cytotoxic T-lymphocytes in primary nodal diffuse large B-cell lymphomas. Leukemia 18: 589-596, 2004.

58. Nakano O, Sato M, Naito Y, Suzuki K, Orikasa S, Aizawa M, Suzuki Y, Shintaku I, Nagura H and Ohtani H: Proliferative activity of intratumoral CD8(+) T-lymphocytes as a prognostic factor in human renal cell carcinoma: Clinicopathologic demonstration of antitumor immunity. Cancer Res 61: 5132-5136, 2001

59. Remark R, Alifano M, Cremer I, Lupo A, Dieu-Nosjean MC, Riquet M, Crozet L, Ouakrim H, Goc J, Cazes A, et al Characteristics and clinical impacts of the immune environments in colorectal and renal cell carcinoma lung metastases: Influence of tumor origin. Clin Cancer Res 19: 4079-4091, 2013.
60. Mori M, Ohtani H, Naito Y, Sagawa M, Sato M, Fujimura S and Nagura H: Infiltration of $\mathrm{CD} 8^{+} \mathrm{T}$ cells in non-small cell lung cancer is associated with dedifferentiation of cancer cells, but not with prognosis. Tohoku J Exp Med 191: 113-118, 2000.

61. Sharpe AH: Introduction to checkpoint inhibitors and cancer immunotherapy. Immunol Rev 276: 5-8, 2017.

62. Chongsathidkiet P, Farber SH, Woroniecka K, Elsamadicy AA, Cui X and Fecci P: IMST-11: Downregulation of sphingosine-1-phosphate receptor type 1 mediates bone marrow T-cell sequestration in patients and mice with glioblastoma. Neuro Oncol 18 (Suppl 6): vi88, 2016.

63. Chang AL, Miska J, Wainwright DA, Dey M, Rivetta CV, Yu D, Kanojia D, Pituch KC, Qiao J, Pytel P, et al: CCL2 produced by the glioma microenvironment is essential for the recruitment of regulatory $\mathrm{T}$ cells and myeloid-derived suppressor cells. Cancer Res 76: 5671-5682, 2016

64. Mitsuka K, Kawataki T, Satoh E, Asahara T, Horikoshi T and Kinouchi H: Expression of indoleamine 2,3-dioxygenase and correlation with pathological malignancy in gliomas. Neurosurgery 72: 1031-1039, 2013

65. Komori T: The 2016 WHO classification of tumors of the central nervous system: The major points of revision. Neurol Med Chir (Tokyo) 57: 301-311, 2017.

66. Chen PL, Roh W, Reuben A, Cooper ZA, Spencer CN, Prieto PA, Miller JP, Bassett RL, Gopalakrishnan V, Wani K, et al: Analysis of immune signatures in longitudinal tumor samples yields insight into biomarkers of response and mechanisms of resistance to immune checkpoint blockade. Cancer Discov 6: 827-837, 2016.

67. Freeman CR and Farmer JP: Pediatric brain stem gliomas: A review. Int J Radiat Oncol Biol Phys 40: 265-271, 1998.

68. Rubin G, Michowitz S, Horev G, Herscovici Z, Cohen IJ, Shuper A and Rappaport ZH: Pediatric brain stem gliomas: An update. Childs Nerv Syst 14: 167-173, 1998.

69. Epstein FJ and Farmer JP: Brain-stem glioma growth patterns. J Neurosurg 78: 408-412, 1993.

70. Epstein F and Constantini S: Practical decisions in the treatment of pediatric brain stem tumors. Pediatr Neurosurg 24: 24-34, 1996.

71. Robertson PL, Allen JC, Abbott IR, Miller DC, Fidel J and Epstein FJ: Cervicomedullary tumors in children: A distinct subset of brainstem gliomas. Neurology 44: 1798-1803, 1994

72. Pollack IF, Hoffman HJ, Humphreys RP and Becker L: The long-term outcome after surgical treatment of dorsally exophytic brain-stem gliomas. J Neurosurg 78: 859-863, 1993.

73. Fisher PG, Breiter SN, Carson BS, Wharam MD, Williams JA, Weingart JD, Foer DR, Goldthwaite PT, Tihan T and Burger PC: A clinicopathologic reappraisal of brain stem tumor classification. Identification of pilocystic astrocytoma and fibrillary astrocytoma as distinct entities. Cancer 89: 1569-1576, 2000.

74. Warren K: DIPG: Poised for progress. Front Oncol 2: 205, 2012.

75. Vanan MI and Eisenstat DD: DIPG in children - what can we learn from the past? Front Oncol 5: 237, 2015.

76. Ridler C: Neuro-oncology: New therapeutic targets for diffuse intrinsic pontine glioma. Nat Rev Neurol 13: 196, 2017.

77. Schroeder KM, Hoeman CM and Becher OJ: Children are not just little adults: Recent advances in understanding of diffuse intrinsic pontine glioma biology. Pediatr Res 75: 205-209, 2014.

78. Disis ML: Immune regulation of cancer. J Clin Oncol 28: 4531-4538, 2010

79. Lewis PW, Müller MM, Koletsky MS, Cordero F, Lin S, Banaszynski LA, Garcia BA, Muir TW, Becher OJ and Allis CD Inhibition of PRC2 activity by a gain-of-function $\mathrm{H} 3$ mutation found in pediatric glioblastoma. Science 340: 857-861, 2013.

80. Zhang L, Chen LH, Wan H, Yang R, Wang Z, Feng J, Yang S, Jones S, Wang S, Zhou W, et al: Exome sequencing identifies somatic gain-of-function PPM1D mutations in brainstem gliomas. Nat Genet 46: 726-730, 2014.

81. Gwak HS and Park HJ: Developing chemotherapy for diffuse pontine intrinsic gliomas (DIPG). Crit Rev Oncol Hematol 120: $111-119,2017$

82. Dong H, Strome SE, Salomao DR, Tamura H, Hirano F, Flies DB Roche PC, Lu J, Zhu G, Tamada K, et al: Tumor-associated B7-H1 promotes T-cell apoptosis: A potential mechanism of immune evasion. Nat Med 8: 793-800, 2002.

83. Wang ZJ, Rao L, Bhambhani K, Miller K, Poulik J, Altinok D and Sood S: Diffuse intrinsic pontine glioma biopsy: A single institution experience. Pediatr Blood Cancer 62: 163-165, 2015.

84. Anderson RC, Kennedy B, Yanes CL, Garvin J, Needle M, Canoll P, Feldstein NA and Bruce JN: Convection-enhanced delivery of topotecan into diffuse intrinsic brainstem tumors in children. J Neurosurg Pediatr 11: 289-295, 2013. 
85. Monje M, Mitra SS, Freret ME, Raveh TB, Kim J, Masek M, Attema JL, Li G, Haddix T, Edwards MS, et al: Hedgehogresponsive candidate cell of origin for diffuse intrinsic pontine glioma. Proc Natl Acad Sci USA 108: 4453-4458, 2011.

86. Morales La Madrid A, Hashizume R and Kieran MW: Future clinical trials in DIPG: Bringing epigenetics to the clinic. Front Oncol 5: 148, 2015.

87. Grasso CS, Tang Y, Truffaux N, Berlow NE, Liu L, Debily MA, Quist MJ, Davis LE, Huang EC, Woo PJ, et al: Functionally defined therapeutic targets in diffuse intrinsic pontine glioma. Nat Med 21: 555-559, 2015.

88. Murakami T, Sato A, Chun NA, Hara M, Naito Y, Kobayashi Y, Kano Y, Ohtsuki M, Furukawa Y and Kobayashi E: Transcriptional modulation using HDACi depsipeptide promotes immune cell-mediated tumor destruction of murine B16 melanoma. J Invest Dermatol 128: 1506-1516, 2008.

89. Magner WJ, Kazim AL, Stewart C, Romano MA, Catalano G, Grande C, Keiser N, Santaniello F and Tomasi TB: Activation of MHC class I, II, and CD40 gene expression by histone deacetylase inhibitors. J Immunol 165: 7017-7024, 2000

90. Armeanu S, Bitzer M, Lauer UM, Venturelli S, Pathil A, Krusch M, Kaiser S, Jobst J, Smirnow I, Wagner A, et al: Natura killer cell-mediated lysis of hepatoma cells via specific induction of NKG2D ligands by the histone deacetylase inhibitor sodium valproate. Cancer Res 65: 6321-6329, 2005.

91. Kroesen M, Gielen P, Brok IC, Armandari I, Hoogerbrugge PM and Adema GJ: HDAC inhibitors and immunotherapy; a double edged sword? Oncotarget 5: 6558-6572, 2014.

92. Schläger C, Körner H, Krueger M, Vidoli S, Haberl M, Mielke D, Brylla E, Issekutz T, Cabañas C, Nelson PJ, et al: Effector T-cel trafficking between the leptomeninges and the cerebrospinal fluid. Nature 530: 349-353, 2016.

93. Louveau A, Smirnov I, Keyes TJ, Eccles JD, Rouhani SJ, Peske JD, Derecki NC, Castle D, Mandell JW, Lee KS, et al Structural and functional features of central nervous system lymphatic vessels. Nature 523: 337-341, 2015.

94. Aspelund A, Antila S, Proulx ST, Karlsen TV, Karaman S, Detmar M, Wiig H and Alitalo K: A dural lymphatic vascular system that drains brain interstitial fluid and macromolecules. J Exp Med 212: 991-999, 2015.

95. Sampson JH, Maus MV and June CH: Immunotherapy for brain tumors. J Clin Oncol 35: 2450-2456, 2017.

96. Frazier JL, Lee J, Thomale UW, Noggle JC, Cohen KJ and Jallo GI: Treatment of diffuse intrinsic brainstem gliomas: Failed approaches and future strategies. J Neurosurg Pediatr 3: 259-269, 2009

97. Ye Z, Qian Q, Jin H and Qian Q: Cancer vaccine: Learning lessons from immune checkpoint inhibitors. J Cancer 9 : 263-268, 2018.

98. Mellman I, Coukos G and Dranoff G: Cancer immunotherapy comes of age. Nature 480: 480-489, 2011.

99. Wainwright DA, Nigam P, Thaci B, Dey M and Lesniak MS: Recent developments on immunotherapy for brain cancer. Expert Opin Emerg Drugs 17: 181-202, 2012.

100. Sonabend AM, Ogden AT, Maier LM, Anderson DE, Canoll P, Bruce JN and Anderson RC: Medulloblasoma: Challenges for effective immunotherapy. J Neurooncol 108: 1-10, 2012.

101.Lennerz V, Fatho M, Gentilini C, Frye RA, Lifke A, Ferel D, Wölfel C, Huber C and Wölfel T: The response of autologous $\mathrm{T}$ cells to a human melanoma is dominated by mutated neoantigens. Proc Natl Acad Sci USA 102: 16013-16018, 2005

102.Zhou J, Dudley ME, Rosenberg SA and Robbins PF: Persistence of multiple tumor-specific T-cell clones is associated with complete tumor regression in a melanoma patient receiving adoptive cell transfer therapy. J Immunother 28: 53-62, 2005.

103. Yuan J, Hegde PS, Clynes R, Foukas PG, Harari A, Kleen TO, Kvistborg P, Maccalli C, Maecker HT, Page DB, et al: Novel technologies and emerging biomarkers for personalized cancer immunotherapy. J Immunother Cancer 4: 3, 2016.

104. Bobisse S, Foukas PG, Coukos G and Harari A: Neoantigen-based cancer immunotherapy. Ann Transl Med 4: 262, 2016.

105. Wang RF and Wang HY: Immune targets and neoantigens for cancer immunotherapy and precision medicine. Cell Res 27 11-37, 2017.

106. Segal NH, Parsons DW, Peggs KS, Velculescu V, Kinzler KW, Vogelstein B and Allison JP: Epitope landscape in breast and colorectal cancer. Cancer Res 68: 889-892, 2008.

107. Joyce JA and Fearon DT: T cell exclusion, immune privilege, and the tumor microenvironment. Science 348: 74-80, 2015

108. Schumacher TN and Schreiber RD: Neoantigens in cancer immunotherapy. Science 348: 69-74, 2015.
109. Pollack IF, Jakacki RI, Butterfield LH, Hamilton RL, Panigrahy A, Potter DM, Connelly AK, Dibridge SA, Whiteside TL and Okada H: Antigen-specific immune responses and clinical outcome after vaccination with glioma-associated antigen peptides and polyinosinic-polycytidylic acid stabilized by lysine and carboxymethylcellulose in children with newly diagnosed malignant brainstem and nonbrainstem gliomas. J Clin Oncol 32: 2050-2058, 2014.

110. Pollack IF, Jakacki RI, Butterfield LH, Hamilton RL, Panigrahy A, Normolle DP, Connelly AK, Dibridge S, Mason G, Whiteside TL, et al: Immune responses and outcome after vaccination with glioma-associated antigen peptides and poly-ICLC in a pilot study for pediatric recurrent low-grade gliomas. Neuro Oncol 18 1157-1168, 2016.

111. Chheda ZS, Kohanbash G, Okada K, Jahan N, Sidney J, Pecoraro M, Yang X, Carrera DA, Downey KM, Shrivastav S, et al: Novel and shared neoantigen derived from histone 3 variant H3.3K27M mutation for glioma T cell therapy. J Exp Med 215: 141-157, 2018.

112. Ochs K, Ott M, Bunse T, Sahm F, Bunse L, Deumelandt K, Sonner JK, Keil M, von Deimling A, Wick W, et al: K27M-mutant histone-3 as a novel target for glioma immunotherapy. Oncoimmunology 6: e1328340, 2017.

113. Anagnostou V, Smith KN, Forde PM, Niknafs $\mathrm{N}$, Bhattacharya R, White J, Zhang T, Adleff V, Phallen J, Wali N, et al: Evolution of neoantigen landscape during immune checkpoint blockade in non-small cell lung cancer. Cancer Discov 7: 264-276, 2017

114. Riaz N, Morris L, Havel JJ, Makarov V, Desrichard A and Chan TA: The role of neoantigens in response to immune checkpoint blockade. Int Immunol 28: 411-419, 2016.

115. Gubin MM, Zhang X, Schuster H, Caron E, Ward JP, Noguchi T, Ivanova Y, Hundal J, Arthur CD, Krebber WJ, et al: Checkpoint blockade cancer immunotherapy targets tumour-specific mutant antigens. Nature 515: 577-581, 2014.

116. Ott PA, Hu Z, Keskin DB, Shukla SA, Sun J, Bozym DJ, Zhang W, Luoma A, Giobbie-Hurder A, Peter L, et al: An immunogenic personal neoantigen vaccine for patients with melanoma. Nature 547: 217-221, 2017

117. Zhou Z, Luther N, Ibrahim GM, Hawkins C, Vibhakar R, Handler MH and Souweidane MM: B7-H3, a potential therapeutic target, is expressed in diffuse intrinsic pontine glioma. J Neurooncol 111: 257-264, 2013.

118. Zang X, Thompson RH, Al-Ahmadie HA, Serio AM, Reuter VE, Eastham JA, Scardino PT, Sharma P and Allison JP: B7-H3 and B7x are highly expressed in human prostate cancer and associated with disease spread and poor outcome. Proc Natl Acad Sci USA 104: 19458-19463, 2007.

119. Lee H, Kim JH, Yang SY, Kong J, Oh M, Jeong DH, Chung JI, Bae KB, Shin JY, Hong KH, et al: Peripheral blood gene expression of B7 and CD28 family members associated with tumor progression and microscopic lymphovascular invasion in colon cancer patients. J Cancer Res Clin Oncol 136: 1445-1452, 2010.

120. Yamato I, Sho M, Nomi T, Akahori T, Shimada K, Hotta K, Kanehiro H, Konishi N, Yagita H and Nakajima Y: Clinical importance of B7-H3 expression in human pancreatic cancer. Br J Cancer 101: 1709-1716, 2009.

121. Crispen PL, Sheinin Y, Roth TJ, Lohse CM, Kuntz SM, Frigola X, Thompson RH, Boorjian SA, Dong H, Leibovich BC, et al: Tumor cell and tumor vasculature expression of B7-H3 predict survival in clear cell renal cell carcinoma. Clin Cancer Res 14: 5150-5157, 2008.

122. Zang X, Sullivan PS, Soslow RA, Waitz R, Reuter VE, Wilton A, Thaler HT, Arul M, Slovin SF, Wei J, et al: Tumor associated endothelial expression of $\mathrm{B} 7-\mathrm{H} 3$ predicts survival in ovarian carcinomas. Mod Pathol 23: 1104-1112, 2010.

123. Boorjian SA, Sheinin Y, Crispen PL, Farmer SA, Lohse CM, Kuntz SM, Leibovich BC, Kwon ED and Frank I: T-cell coregulatory molecule expression in urothelial cell carcinoma: Clinicopathologic correlations and association with survival. Clin Cancer Res 14: 4800-4808, 2008.

124. Griesinger AM, Birks DK, Donson AM, Amani V, Hoffman LM, Waziri A, Wang $M$, Handler $\mathrm{MH}$ and Foreman $\mathrm{NK}$ : Characterization of distinct immunophenotypes across pediatric brain tumor types. J Immunol 191: 4880-4888, 2013.

125. Liu D, Song L, Brawley VS, Robison N, Wei J, Gao X, Tian G, Margol A, Ahmed N, Asgharzadeh S, et al: Medulloblastoma expresses CD1d and can be targeted for immunotherapy with NKT cells. Clin Immunol 149: 55-64, 2013. 
126. Ahmed N, Ratnayake M, Savoldo B, Perlaky L, Dotti G, Wels WS, Bhattacharjee MB, Gilbertson RJ, Shine HD, Weiss HL, et al: Regression of experimental medulloblastoma following transfer of HER2-specific T cells. Cancer Res 67: 5957-5964, 2007

127. Hussain SF, Yang D, Suki D, Aldape K, Grimm E and Heimberger AB: The role of human glioma-infiltrating microglia/ macrophages in mediating antitumor immune responses. Neuro Oncol 8: 261-279, 2006.

128.Zeng J, See AP, Phallen J, Jackson CM, Belcaid Z, Ruzevick J, Durham N, Meyer C, Harris TJ, Albesiano E, et al: Anti-PD-1 blockade and stereotactic radiation produce long-term survival in mice with intracranial gliomas. Int $\mathbf{J}$ Radiat Oncol Biol Phys 86: 343-349, 2013.

129. Fecci PE, Ochiai H, Mitchell DA, Grossi PM, Sweeney AE, Archer GE, Cummings T, Allison JP, Bigner DD and Sampson JH: Systemic CTLA-4 blockade ameliorates glioma-induced changes to the $\mathrm{CD} 4^{+} \mathrm{T}$ cell compartment without affecting regulatory T-cell function. Clin Cancer Res 13: 2158-2167, 2007.

130. Berghoff AS, Kiesel B, Widhalm G, Rajky O, Ricken G, Wöhrer A, Dieckmann K, Filipits M, Brandstetter A, Weller M, et al: Programmed death ligand 1 expression and tumorinfiltrating lymphocytes in glioblastoma. Neuro Oncol 17: $1064-1075,2015$.

131. Garrido F, Aptsiauri N, Doorduijn EM, Garcia Lora AM and van Hall T: The urgent need to recover MHC class I in cancers for effective immunotherapy. Curr Opin Immunol 39: 44-51, 2016.

132. Warren K, Bent R, Wolters PL, Prager A, Hanson R, Packer R, Shih $\mathrm{J}$ and Camphausen $\mathrm{K}$ : A phase 2 study of pegylated interferon $\alpha-2 b$ (PEG-Intron(®)) in children with diffuse intrinsic pontine glioma. Cancer 118: 3607-3613, 2012.

133. Greil R, Hutterer E, Hartmann TN and Pleyer L: Reactivation of dormant anti-tumor immunity - a clinical perspective of therapeutic immune checkpoint modulation. Cell Commun Signal 15: 5, 2017.

134. Khanna R: Tumour surveillance: Missing peptides and MHC molecules. Immunol Cell Biol 76: 20-26, 1998.

135. Campoli $\mathrm{M}$ and Ferrone S: HLA antigen changes in malignant cells: Epigenetic mechanisms and biologic significance. Oncogene 27: 5869-5885, 2008

136.Zhang HG, Wang J, Yang X, Hsu HC and Mountz JD: Regulation of apoptosis proteins in cancer cells by ubiquitin. Oncogene 23 2009-2015, 2004

137. Ozören N and El-Deiry WS: Cell surface Death Receptor signaling in normal and cancer cells. Semin Cancer Biol 13: $135-147,2003$

138. Wu Y, Chen M, Wu P, Chen C, Xu ZP and Gu W: Increased PD-L1 expression in breast and colon cancer stem cells. Clin Exp Pharmacol Physiol 44: 602-604, 2017

139. Zitvogel L and Kroemer G: Targeting PD-1/PD-L1 interactions for cancer immunotherapy. Oncoimmunology 1: 1223-1225, 2012

140. He J, Hu Y, Hu M and Li B: Development of PD-1/PD-L1 pathway in tumor immune microenvironment and treatment for non-small cell lung cancer. Sci Rep 5: 13110, 2015.

141.Dolan DE and Gupta S: PD-1 pathway inhibitors: Changing the landscape of cancer immunotherapy. Cancer Contr 21: 231-237, 2014

142.Picarda E, Ohaegbulam KC and Zang X: Molecular pathways: Targeting B7-H3 (CD276) for human cancer immunotherapy. Clin Cancer Res 22: 3425-3431, 2016.

143.Jiang B, Liu F, Liu Z, Zhang T and Hua D: B7-H3 increases thymidylate synthase expression via the PI3k-Akt pathway. Tumour Biol 37: 9465-9472, 2016.

144. Silva TG, Crispim JC, Miranda FA, Hassumi MK, de Mello JM, Simões RT, Souto F, Soares EG, Donadi EA and Soares CP: Expression of the nonclassical HLA-G and HLA-E molecules in laryngeal lesions as biomarkers of tumor invasiveness. Histo Histopathol 26: 1487-1497, 2011.

145.Zang X, Loke P, Kim J, Murphy K, Waitz R and Allison JP: B7x: a widely expressed B7 family member that inhibits T cel activation. Proc Natl Acad Sci USA 100: 10388-10392, 2003.

146. Mahoney KM, Rennert PD and Freeman GJ: Combination cancer immunotherapy and new immunomodulatory targets. Nat Rev Drug Discov 14: 561-584, 2015.

147. Hou J, Greten TF and Xia Q: Immunosuppressive cell death in cancer. Nat Rev Immunol 17: 401, 2017.

148. Joshi BH, Plautz GE and Puri RK: Interleukin-13 receptor alpha chain: A novel tumor-associated transmembrane protein in primary explants of human malignant gliomas. Cancer Res 60: $1168-1172,2000$
149. Okano F, Storkus WJ, Chambers WH, Pollack IF and Okada H: Identification of a novel HLA-A*0201-restricted, cytotoxic $\mathrm{T}$ lymphocyte epitope in a human glioma-associated antigen, interleukin 13 receptor alpha2 chain. Clin Cancer Res 8: 2851-2855, 2002.

150. Tsuda N, Nonaka Y, Shichijo S, Yamada A, Ito M, Maeda Y, Harada M, Kamura T and Itoh K: UDP-Gal: betaGlcNAc beta1, 3-galactosyltransferase, polypeptide 3(GALT3) is a tumour antigen recognised by HLA-A2-restricted cytotoxic T lymphocytes from patients with brain tumour. Br J Cancer 87: 1006-1012, 2002.

151. Schmitz M, Temme A, Senner V, Ebner R, Schwind S, Stevanovic S, Wehner R, Schackert G, Schackert HK, Fussel M, et al: Identification of SOX2 as a novel glioma-associated antigen and potential target for $\mathrm{T}$ cell-based immunotherapy. $\mathrm{Br}$ J Cancer 96: 1293-1301, 2007.

152. Heimberger AB, Hlatky R, Suki D, Yang D, Weinberg J, Gilbert M, Sawaya R and Aldape K: Prognostic effect of epidermal growth factor receptor and EGFRvIII in glioblastoma multiforme patients. Clin Cancer Res 11: 1462-1466, 2005.

153. Ueda R, Iizuka Y, Yoshida K, Kawase T, Kawakami Y and Toda M: Identification of a human glioma antigen, SOX6, recognized by patients' sera. Oncogene 23: 1420-1427, 2004.

154. Pallasch CP, Struss AK, Munnia A, König J, Steudel WI, Fischer U and Meese E: Autoantibodies against GLEA2 and PHF3 in glioblastoma: Tumor-associated autoantibodies correlated with prolonged survival. Int J Cancer 117: 456-459, 2005.

155. Arnon TI, Markel G and Mandelboim O: Tumor and viral recognition by natural killer cells receptors. Semin Cancer Biol 16: 348-358, 2006.

156. Wu A, Wiesner S, Xiao J, Ericson K, Chen W, Hall WA, Low WC and Ohlfest JR: Expression of MHC I and NK ligands on human $\mathrm{CD}_{133^{+}}$glioma cells: Possible targets of immunotherapy. J Neurooncol 83: 121-131, 2007.

157. Eisele G, Wischhusen J, Mittelbronn M, Meyermann R, Waldhauer I, Steinle A, Weller M and Friese MA: TGF-beta and metalloproteinases differentially suppress NKG2D ligand surface expression on malignant glioma cells. Brain 129: 2416-2425, 2006

158. Groh V, Bahram S, Bauer S, Herman A, Beauchamp M and Spies T: Cell stress-regulated human major histocompatibility complex class I gene expressed in gastrointestinal epithelium. Proc Natl Acad Sci USA 93: 12445-12450, 1996.

159. Hatano M, Eguchi J, Tatsumi T, Kuwashima N, Dusak JE, Kinch MS, Pollack IF, Hamilton RL, Storkus WJ and Okada H: EphA2 as a glioma-associated antigen: A novel target for glioma vaccines. Neoplasia 7: 717-722, 2005.

160. Zhang JG, Eguchi J, Kruse CA, Gomez GG, Fakhrai H, Schroter S, Ma W, Hoa N, Minev B, Delgado C, et al: Antigenic profiling of glioma cells to generate allogeneic vaccines or dendritic cellbased therapeutics. Clin Cancer Res 13: 566-575, 2007.

161. Jin M, Komohara Y, Shichijo S, Harada M, Yamanaka R, Miyamoto S, Nikawa J, Itoh K and Yamada A: Identification of EphB6 variant-derived epitope peptides recognized by cytotoxic T-lymphocytes from HLA-A $24^{+}$malignant glioma patients. Oncol Rep 19: 1277-1283, 2008

162. Liu G, Yu JS, Zeng G, Yin D, Xie D, Black KL and Ying H: AIM-2: A novel tumor antigen is expressed and presented by human glioma cells. J Immunother 27: 220-226, 2004.

163. Imaizumi T, Kuramoto T, Matsunaga K, Shichijo S, Yutani S, Shigemori M, Oizumi K and Itoh K: Expression of the tumorrejection antigen SART1 in brain tumors. Int J Cancer 83: 760-764, 1999

164. Murayama K, Kobayashi T, Imaizumi T, Matsunaga K, Kuramoto T, Shigemori M, Shichijo S and Itoh K: Expression of the SART3 tumor-rejection antigen in brain tumors and induction of cytotoxic T lymphocytes by its peptides. J Immunother 23: 511-518, 2000

165. Liu G, Ying H, Zeng G, Wheeler CJ, Black KL and Yu JS HER-2, gp100, and MAGE-1 are expressed in human glioblastoma and recognized by cytotoxic T cells. Cancer Res 64 : 4980-4986, 2004

166. Saikali S, Avril T, Collet B, Hamlat A, Bansard JY, Drenou B, Guegan Y and Quillien V: Expression of nine tumour antigens in a series of human glioblastoma multiforme: Interest of EGFRvIII, IL-13Ralpha2, gp100 and TRP-2 for immunotherapy. J Neurooncol 81: 139-148, 2007.

167. Liu G, Khong HT, Wheeler CJ, Yu JS, Black KL and Ying H: Molecular and functional analysis of tyrosinase-related protein (TRP)-2 as a cytotoxic T lymphocyte target in patients with malignant glioma. J Immunother 26: 301-312, 2003 
168. Chi DD, Merchant RE, Rand R, Conrad AJ, Garrison D, Turner R, Morton DL and Hoon DS: Molecular detection of tumorassociated antigens shared by human cutaneous melanomas and gliomas. Am J Pathol 150: 2143-2152, 1997.

169. Facoetti A, Nano R,Zelini P, Morbini P, Benericetti E, Ceroni M, Campoli $\mathrm{M}$ and Ferrone S: Human leukocyte antigen and antigen processing machinery component defects in astrocytic tumors. Clin Cancer Res 11: 8304-8311, 2005.

170.Sampson JH, Heimberger AB, Archer GE, Aldape KD, Friedman AH, Friedman HS, Gilbert MR, Herndon JE II, McLendon RE, Mitchell DA, et al: Immunologic escape after prolonged progression-free survival with epidermal growth factor receptor variant III peptide vaccination in patients with newly diagnosed glioblastoma. J Clin Oncol 28: 4722-4729, 2010

171.Zagzag D, Salnikow K, Chiriboga L, Yee H, Lan L, Ali MA, Garcia R, Demaria S and Newcomb EW: Downregulation of major histocompatibility complex antigens in invading glioma cells: Stealth invasion of the brain. Lab Invest 85: 328-341, 2005.

172. Mehling M, Simon P, Mittelbronn M, Meyermann R, Ferrone S, Weller M and Wiendl $\mathrm{H}$ : WHO grade associated downregulation of MHC class I antigen-processing machinery components in human astrocytomas: Does it reflect a potential immune escape mechanism? Acta Neuropathol 114: 111-119, 2007.

173. Crane CA, Han SJ, Barry JJ, Ahn BJ, Lanier LL and Parsa AT: TGF-beta downregulates the activating receptor NKG2D on NK cells and $\mathrm{CD}^{+} \mathrm{T}$ cells in glioma patients. Neuro Oncol 12: 7-13, 2010.

174. Groh V, Wu J, Yee C and Spies T: Tumour-derived soluble MIC ligands impair expression of NKG2D and T-cell activation. Nature 419: 734-738, 2002.

175. Bodmer S, Strommer K, Frei K, Siepl C, de Tribolet N, Heid I and Fontana A: Immunosuppression and transforming growth factor-beta in glioblastoma. Preferential production of transforming growth factor-beta 2. J Immunol 143: 3222-3229, 1989.

176. Wrann M, Bodmer S, de Martin R, Siepl C, Hofer-Warbinek R Frei K, Hofer E and Fontana A: T cell suppressor factor from human glioblastoma cells is a 12.5 -kd protein closely related to transforming growth factor-beta. EMBO J 6: 1633-1636, 1987.

177. Wei J, Barr J, Kong LY, Wang Y, Wu A, Sharma AK, Gumin J, Henry V, Colman H, Priebe W, et al: Glioblastoma cancerinitiating cells inhibit T-cell proliferation and effector responses by the signal transducers and activators of transcription 3 pathway. Mol Cancer Ther 9: 67-78, 2010.

178. de Martin R, Haendler B, Hofer-Warbinek R, Gaugitsch $\mathrm{H}$ Wrann M, Schlüsener H, Seifert JM, Bodmer S, Fontana A and Hofer E: Complementary DNA for human glioblastoma-derived $\mathrm{T}$ cell suppressor factor, a novel member of the transforming growth factor-beta gene family. EMBO J 6: 3673-3677, 1987.

179. Gide TN, Wilmott JS, Scolyer RA and Long GV: Primary and acquired resistance to immune checkpoint inhibitors in metastatic melanoma. Clin Cancer Res: Nov 10, 2017 (Epub ahead of print). doi: 10.1158/1078-0432.CCR-17-2267.

180. Miao D, De Velasco G, Adeegbe D, Norton C, Martini D, Mullane S, Moreira R, Signoretti S, Wong KK, Choueiri T and Van Allen E: Genomic and neoantigen evolution and resistance to immune checkpoint blockade in metastatic renal cel carcinoma. Cancer Immunol Res 5: 3, 2017.

181. Gao X, Zhu Y, Li G, Huang H, Zhang G, Wang F, Sun J, Yang Q, Zhang $\mathrm{X}$ and Lu B: TIM-3 expression characterizes regulatory $\mathrm{T}$ cells in tumor tissues and is associated with lung cancer progression. PLoS One 7: e30676, 2012.

182. Yang ZZ, Grote DM,Ziesmer SC,Niki T, Hirashima M, Novak AJ, Witzig TE and Ansell SM: IL-12 upregulates TIM-3 expression and induces $\mathrm{T}$ cell exhaustion in patients with follicular B cell non-Hodgkin lymphoma. J Clin Invest 122: 1271-1282, 2012.

183. Andrews LP, Marciscano AE, Drake CG and Vignali DA: LAG3 (CD223) as a cancer immunotherapy target. Immunol Rev 276: 80-96, 2017.

184. Śledzińska A, Menger L, Bergerhoff K, Peggs KS and Quezada SA: Negative immune checkpoints on $\mathrm{T}$ lymphocytes and their relevance to cancer immunotherapy. Mol Oncol 9: 1936-1965, 2015.

185. Matsuzaki J, Gnjatic S, Mhawech-Fauceglia P, Beck A, Miller A, Tsuji T, Eppolito C, Qian F, Lele S, Shrikant P, et al: Tumorinfiltrating NY-ESO-1-specific $\mathrm{CD}{ }^{+} \mathrm{T}$ cells are negatively regulated by LAG-3 and PD-1 in human ovarian cancer. Proc Natl Acad Sci USA 107: 7875-7880, 2010

186. Woo SR, Turnis ME, Goldberg MV, Bankoti J, Selby M, Nirschl CJ, Bettini ML, Gravano DM, Vogel P, Liu CL, et al Immune inhibitory molecules LAG-3 and PD-1 synergistically regulate T-cell function to promote tumoral immune escape. Cancer Res 72: 917-927, 2012
187. Yu X, Harden K, Gonzalez LC, Francesco M, Chiang E, Irving B, Tom I, Ivelja S, Refino CJ, Clark H, et al: The surface protein TIGIT suppresses $\mathrm{T}$ cell activation by promoting the generation of mature immunoregulatory dendritic cells. Nat Immunol 10: 48-57, 2009.

188. Monney L, Sabatos CA, Gaglia JL, Ryu A, WaldnerH, Chernova T, Manning S, Greenfield EA, Coyle AJ, Sobel RA, et al: Th1-specific cell surface protein Tim-3 regulates macrophage activation and severity of an autoimmune disease. Nature 415: 536-541, 2002.

189. Sakuishi K, Apetoh L, Sullivan JM, Blazar BR, Kuchroo VK and Anderson AC: Targeting Tim-3 and PD-1 pathways to reverse $\mathrm{T}$ cell exhaustion and restore anti-tumor immunity. J Exp Med 207: 2187-2194, 2010.

190. Lines JL, Pantazi E, Mak J, Sempere LF, Wang L, O'Connell S, Ceeraz S, Suriawinata AA, Yan S, Ernstoff MS, et al: VISTA is an immune checkpoint molecule for human T cells. Cancer Res 74: 1924-1932, 2014.

191. Beard RE, Abate-Daga D, Rosati SF, Zheng Z, Wunderlich JR, Rosenberg SA and Morgan RA: Gene expression profiling using nanostring digital RNA counting to identify potential target antigens for melanoma immunotherapy. Clin Cancer Res 19: 4941-4950, 2013.

192. Ryall S, Arnoldo A, Krishnatry R, Mistry M, Khor K, Sheth J, Ling C, Leung S, Zapotocky M, Guerreiro Stucklin A, et al: Multiplex detection of pediatric low-grade glioma signature fusion transcripts and duplications using the NanoString nCounter system. J Neuropathol Exp Neurol 76: 562-570, 2017.

193. Chen H, Judkins J, Thomas C, Wu M, Khoury L, Benjamin CG, Pacione D, Golfinos JG, Kumthekar P, Ghamsari F, et al: Mutant IDH1 and seizures in patients with glioma. Neurology 88: 1805-1813, 2017

194. Bassoy EY, Kasahara A, Chiusolo V, Jacquemin G, Boydell E, Zamorano S, Riccadonna C, Pellegatta S, Hulo N, Dutoit V, et al: ER-mitochondria contacts control surface glycan expression and sensitivity to killer lymphocytes in glioma stem-like cells. EMBO J 36: 1493-1512, 2017.

195. Wells E, Kambhampati M, Damsker JM, Gordish-Dressman H, Yadavilli S, Becher OJ, Gittens J, Stampar M, Packer RJ and Nazarian J, et al: Vamorolone, a dissociative steroidal compound, reduces pro-inflammatory cytokine expression in glioma cells and increases activity and survival in a murine model of cortical tumor. Oncotarget 8: 9366-9374, 2017.

196. Rusiecki D, Lach B, Manoranjan B, Fleming A, Ajani O and Singh SK: Progression of atypical extraventricular neurocytoma to anaplastic ganglioglioma. Hum Pathol 59: 125-130, 2017.

197. Ryall S, Krishnatry R, Arnoldo A, Buczkowicz P, Mistry M, Siddaway R, Ling C, Pajovic S, Yu M, Rubin JB, et al: Targeted detection of genetic alterations reveal the prognostic impact of H3K27M and MAPK pathway aberrations in paediatric thalamic glioma. Acta Neuropathol Commun 4: 93, 2016

198. Lassaletta A, Scheinemann K, Zelcer SM, Hukin J, Wilson BA, Jabado N, Carret AS, Lafay-Cousin L, Larouche V, Hawkins CE et al: Phase II weekly vinblastine for chemotherapy-naïve children with progressive low-grade glioma: A Canadian Pediatric Brain Tumor Consortium Study. J Clin Oncol 34: 3537-3543, 2016.

199. Antonios JP, Soto H, Everson RG, Orpilla J, Moughon D, Shin N, Sedighim S, Yong WH, Li G, Cloughesy TF, et al: PD-1 blockade enhances the vaccination-induced immune response in glioma. JCI Insight 1: e87059, 2016.

200. Nazarian J, Mason GE, Ho CY,Panditharatna E, Kambhampati M, Vezina LG, Packer RJ and Hwang EI: Histological and molecular analysis of a progressive diffuse intrinsic pontine glioma and synchronous metastatic lesions: A case report. Oncotarget 7: 42837-42842, 2016

201. Quail DF, Bowman RL, Akkari L, Quick ML, Schuhmacher AJ, Huse JT, Holland EC, Sutton JC and Joyce JA: The tumor microenvironment underlies acquired resistance to CSF-1R inhibition in gliomas. Science 352: aad3018, 2016.

202. Flynn A, Dwight T, Harris J, Benn D, Zhou L,Hogg A, Catchpoole D, James P, Duncan EL, Trainer A, et al: Pheo-type: A diagnostic gene-expression assay for the classification of pheochromocytoma and paraganglioma. J Clin Endocrinol Metab 101: 1034-1043, 2016.

203. Nevo I, Woolard K, Cam M, Li A, Webster JD, Kotliarov Y, Kim HS, Ahn S, Walling J, Kotliarova S, et al: Identification of molecular pathways facilitating glioma cell invasion in situ. PLoS One 9: e111783, 2014.

204. Pyonteck SM, Akkari L, Schuhmacher AJ, Bowman RL, Sevenich L, Quail DF, Olson OC, Quick ML, Huse JT, Teijeiro V, et al: CSF-1R inhibition alters macrophage polarization and blocks glioma progression. Nat Med 19: 1264-1272, 2013. 
205.Peruzzi P, Bronisz A, Nowicki MO, Wang Y, Ogawa D, Price R, Nakano I, Kwon CH, Hayes J, Lawler SE, et al: MicroRNA-128 coordinately targets Polycomb Repressor Complexes in glioma stem cells. Neuro Oncol 15: 1212-1224, 2013.

206.Kannan K, Inagaki A, Silber J, Gorovets D, Zhang J, Kastenhuber ER, Heguy A, Petrini JH, Chan TA and Huse JT: Whole exome sequencing identifies ATRX mutation as a key molecular determinant in lower-grade glioma. Oncotarget 3 : 1194-1203, 2012.

207. Sharpe AH and Freeman GJ: The B7-CD28 superfamily. Nat Rev Immunol 2: 116-126, 2002.

208. Brown JA, Dorfman DM,Ma FR,Sullivan EL, Munoz O, Wood CR, Greenfield EA and Freeman GJ: Blockade of programmed death-1 ligands on dendritic cells enhances $\mathrm{T}$ cell activation and cytokine production. J Immunol 170: 1257-1266, 2003.

209. Francisco LM, Sage PT and Sharpe AH: The PD-1 pathway in tolerance and autoimmunity. Immunol Rev 236: 219-242, 2010.

210. Nassar AF, Ogura H and Wisnewski AV: Impact of recent innovations in the use of mass cytometry in support of drug development. Drug Discov Today 20: 1169-1175, 2015.

211. Bendall SC, Simonds EF, Qiu P, Amir AD, Krutzik PO, Finck R, Bruggner RV, Melamed R, Trejo A, Ornatsky OI, et al: Single-cell mass cytometry of differential immune and drug responses across a human hematopoietic continuum. Science 332: 687-696, 2011.

212. Spitzer MH, Carmi Y, Reticker-Flynn NE, Kwek SS, Madhireddy D, Martins MM, Gherardini PF, Prestwood TR, Chabon J, Bendall SC, et al: Systemic immunity is required for effective cancer immunotherapy. Cell 168: 487-502.e15, 2017.

213. Wei SC, Levine JH, Cogdill AP, Zhao Y, Anang NA, Andrews MC, Sharma P, Wang J, Wargo JA, Pe'er D, et al: Distinct cellular mechanisms underlie anti-CTLA-4 and anti-PD-1 checkpoint blockade. Cell 170: 1120-1133.e17, 2017.

214. Omuro A, Chan TA, Abrey LE, Khasraw M, Reiner AS, Kaley TJ, Deangelis LM, Lassman AB, Nolan CP, Gavrilovic IT, et al: Phase II trial of continuous low-dose temozolomide for patients with recurrent malignant glioma. Neuro Oncol 15: 242-250, 2013.

215.Johung TB and Monje M: Diffuse Intrinsic Pontine Glioma: New pathophysiological insights and emerging therapeutics targets. Curr Neuropharmacol 15: 88-97, 2017.

216. Bast RC Jr, Croce CM, Hait WN, Hong WK, Kufe DW, Piccart-Gebhart M, Pollock RE, Weichselbaum RR, Wang H, Holland JF: Holland Frei Cancer Medicine 9th. Wiley Blackwell, p2008, 2017.

217. Fan X, Quezada SA, Sepulveda MA, Sharma P and Allison JP: Engagement of the ICOS pathway markedly enhances efficacy of CTLA-4 blockade in cancer immunotherapy. J Exp Med 211: $715-725,2014$
218. Liakou CI, Kamat A, Tang DN, Chen H, Sun J, Troncoso P, Logothetis C and Sharma P: CTLA-4 blockade increases IFNgamma-producing CD4 ${ }^{+} \mathrm{ICOS}^{\text {hi }}$ cells to shift the ratio of effector to regulatory T cells in cancer patients. Proc Natl Acad Sci USA 105: 14987-14992, 2008.

219. Gao J, Shi LZ, Zhao H, Chen J, Xiong L, He Q, Chen T, Roszik J, Bernatchez C, Woodman SE, et al: Loss of IFN- $\gamma$ pathway genes in tumor cells as a mechanism of resistance to anti-CTLA-4 therapy. Cell 167: 397-404.e9, 2016.

220. O'Donnell JS, Smyth MJ and Teng MW: Acquired resistance to anti-PD1 therapy: Checkmate to checkpoint blockade? Genome Med 8: 111-116, 2016.

221.Zaretsky JM, Garcia-Diaz A, Shin DS, Escuin-Ordinas H, Hugo W, Hu-Lieskovan S, Torrejon DY, Abril-Rodriguez G, Sandoval S, Barthly L, et al: Mutations associated with acquired resistance to PD-1 blockade in melanoma. N Engl J Med 375: 819-829, 2016

222. Morris VK, Salem ME, Nimeiri H, Iqbal S, Singh P, Ciombor K, Polite B, Deming D, Chan E, Wade JL, et al: Nivolumab for previously treated unresectable metastatic anal cancer (NCI9673): A multicentre, single-arm, phase 2 study. Lancet Oncol 18: 446-453, 2017.

223. Robert C, Long GV, Brady B, Dutriaux C, Maio M, Mortier L, Hassel JC, Rutkowski P, McNeil C, Kalinka-Warzocha E, et al: Nivolumab in previously untreated melanoma without BRAF mutation. N Engl J Med 372: 320-330, 2015.

224. Meng X, Huang Z, Teng F, Xing L and Yu J: Predictive biomarkers in PD-1/PD-L1 checkpoint blockade immunotherapy. Cancer Treat Rev 41: 868-876, 2015.

225. Gao J, Ward JF, Pettaway CA, Shi LZ, Subudhi SK, Vence LM, Zhao H, Chen J, Chen H, Efstathiou E, et al: VISTA is an inhibitory immune checkpoint that is increased after ipilimumab therapy in patients with prostate cancer. Nat Med 23: 551-555, 2017.

226. Koyama S, Akbay EA, Li YY, Herter-Sprie GS, Buczkowski KA, Richards WG, Gandhi L, Redig AJ, Rodig SJ, Asahina H, et al: Adaptive resistance to therapeutic PD-1 blockade is associated with upregulation of alternative immune checkpoints. Nat Commun 7: 10501, 2016.

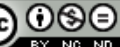

This work is licensed under a Creative Common Attribution-NonCommercial-NoDerivatives 4.0 International (CC BY-NC-ND 4.0) License. 